\title{
The Balance between Reactivity and Stability of Modified Oxide Surfaces Illustrated by the Behavior of Sulfated Zirconia Catalysts
}

\author{
B. S. Klose-Schubert ${ }^{1}$, R. E. Jentoft ${ }^{1,2}$, F. C. Jentoft ${ }^{1,2 *}$ \\ ${ }^{1}$ Department of Inorganic Chemistry, Fritz Haber Institute of the Max Planck Society, \\ Faradayweg 4-6, 14195 Berlin, Germany \\ ${ }^{2}$ School of Chemical, Biological and Materials Engineering, University of Oklahoma,
}

Norman, OK 73019-1004, USA

*Corresponding author: e-mail fcjentoft@ ou.edu,

Published online: 15 February 2011

Dedicated to Bruce C. Gates on the occasion of his $70^{\text {th }}$ birthday

\begin{abstract}
The stability of a series of sulfated zirconia catalysts, promoted with up to $2 \mathrm{wt} \%$ iron or manganese, in their calcined state was investigated. Phase composition, nature of surface sulfate species, degree of hydroxylation, and butane isomerization activity changed during aging over months in various atmospheres and during milling. The metastability of small oxide particles is discussed, including literature data on alumina, titania and other oxides. Catalytically active fractions of a material easily transition into more stable, less active forms.
\end{abstract}

Keywords: Promoted sulfated zirconia; Iron; Manganese; Phase transition; Monoclinic; Tetragonal; Butane isomerization; Mechanical activation; Storage conditions; IR spectroscopy

\section{Introduction}

Catalysts are reactive materials that change their state depending on surrounding conditions. This behavior is typical of an operating catalyst, and in fact, some catalysts are too reactive in their active state to be safely transported, and hence established protocols exist to deliver passivated precursor states, which are filled into the reactor and then activated $[1,2]$. Slight variations in the material define various precursor states of the catalyst, the activated and active states, and the deactivated state. Procedures to reach an active state are well known, and numerous investigations [3-7] have been conducted to identify aging processes and deactivation causes in working catalysts, which may include thermally induced effects such as sintering, segregation or volatilization, mechanically induced effects such as attrition or crushing, or poisoning through feed contaminants or side products.
Little information is available in the open literature about the stability of precursor states, which defines the shelf life, that is, the possible length of the period between manufacture and use. Precursors, although less reactive than an activated or active catalyst, are also not thermodynamically stable because they share many properties with the catalytically active form of the material. The same properties that are needed for high reactivity evoke intrinsic metastability. Most catalyst materials contain nanoscale particles, which are thermodynamically less stable than larger particles because surface energy is always positive. As a consequence of high surface area, the surface energy contribution becomes significant for phase stability, and a different polymorph may become more thermodynamically stable than that which is stable when crystals are large and the bulk energy dominates. Examples are the preference of tetragonal over monoclinic zirconia $[8,9]$ and of $\gamma-\mathrm{Al}_{2} \mathrm{O}_{3}$ over $\alpha-\mathrm{Al}_{2} \mathrm{O}_{3}[10]$ at small particle sizes. The high surface 
area makes catalysts more susceptible to the influences of surrounding fluids because the surface energy will be affected if molecules adsorb. Moreover, surface atoms become mobile at much lower temperature than atoms in the bulk; the Hüttig temperature [11], which characterizes the onset of surface mobility, is always significantly lower than the Tammann temperature [12,13], which characterizes the onset of bulk mobility. As a result, small particles with a high fraction of surface atoms melt at much lower temperatures than bulk crystals; an excellent example is gold [14].

Storage conditions are usually mild, but, particularly in a research environment, samples are often kept for years, so that even seemingly insignificant rates of transformation eventually result in a significant alteration of a sample. Catalyst suppliers with customers around the world have to be concerned because storage time and conditions may be out of their control. Reported examples of aging during storage concern zeolitic catalysts [15,16]; the Brønsted acidity of SAPO-34 was found to decrease during storage in ambient conditions [15] whereas that of steamed $\mathrm{Y}$ zeolites [16] was found to increase. Another example concerns silica-supported silver catalysts; Bron et al. [17] found the conversion and selectivity of these catalysts in acrolein hydrogenation to be higher after five months of storage in air than immediately after preparation.

An interesting candidate for a shelf-life investigation is sulfated zirconia, because both of its components, zirconia and sulfate, easily change their state, and the sulfate may even be removed from the catalyst. Sulfated zirconia [18-20] and its promoted varieties [21-24] are exceptionally active for the low temperature skeletal isomerization of alkanes, making them attractive commercial catalysts.

Zirconia occurs in multiple polymorphs, with active sulfated zirconia catalysts typically containing the tetragonal and sometimes also the monoclinic phase, which has been reported to be inactive [25], or at least 4-5 times less active than the tetragonal zirconia phase [26]. Transformation of the tetragonal to the monoclinic phase is easily initiated by elevated temperatures of 336-673 K, particularly in the presence of water vapor [27] and by mechanical stress in the form of grinding, milling, or pressing [28].

Sulfate can assume a multitude of structures on the surface of zirconia, depending on the loading and on the degree of hydration [29]. Sulfate can be removed or converted to an inactive sulfur-oxygen compound through dissolution in water [30], thermal decomposition [31], or reduction, for example by pyridine or benzene $[32,33]$ or alkane reactants [34]. The promoters iron and manganese were found to render the sulfate more easily reducible [35].

The fact that sulfated zirconia changes during almost any treatment, including those treatments intended to change the material as well as those intended not to - such as specimen preparation for analysis [28] - suggests that the material may also change "without treatment", that is, during storage. While this sensitive behavior presents a challenge in investigating these materials and probably contributes to the reported problem of poor reproducibility
[36-38], it also presents an opportunity to identify properties essential to the catalytic activity.

In this paper, we complement the information available on the thermal and mechanical stability of sulfated zirconia, with an emphasis on promoted materials. We investigate effects during storage over half a year in conditions that mimic the customs and climatic conditions encountered in laboratories in various parts of the world. The conditions include the $\mathrm{H}_{2} \mathrm{O}$ - and $\mathrm{O}_{2}$-depleted environment of a glovebox, simulated "tropical" conditions of $313 \mathrm{~K}$ and saturated water vapor, as well as "normal" laboratory conditions in Central Europe. The discussion includes literature data regarding oxo anions other than sulfate and oxides other than zirconia to achieve a more general picture of the phase stability of small oxide particles and resulting implications on catalytic activity.

\section{Experimental Section}

\subsection{Catalyst Preparation}

X-ray amorphous hydrous zirconia was from MEL chemicals, and either undoped (XZO 632/03) or doped with ammonium sulfate (5-6 wt $\% \mathrm{SO}_{3}$ on the $\mathrm{ZrO}_{2}$ content, XZO 682/01). These precursor materials were dried for 21 $\mathrm{h}$ at $383 \mathrm{~K}$. Samples promoted with 0.5 or $2.0 \mathrm{wt} \%$ iron or manganese were prepared from dried XZO 682 according to the "incipient wetness" impregnation method, using aqueous solutions of either $\mathrm{Mn}\left(\mathrm{NO}_{3}\right)_{2} \cdot 4 \mathrm{H}_{2} \mathrm{O}$ or $\mathrm{Fe}\left(\mathrm{NO}_{3}\right)_{3} \cdot 9 \mathrm{H}_{2} \mathrm{O}$ (both Merck, p.a.). After impregnation the samples were dried at room temperature for at least $24 \mathrm{~h}$. An amount of 20-25 g of raw material was calcined in a $17.1 \mathrm{ml}$ quartz boat under a $200 \mathrm{ml} \mathrm{min}^{-1}$ synthetic air flow, applying a nominal heating rate of $3 \mathrm{~K} \mathrm{~min}^{-1}$ and a holding time of $3 \mathrm{~h}$ [37,38]. Pure and sulfated zirconia were calcined at $823 \mathrm{~K}$ and are designated as "Z" and "SZ". Promoted sulfated zirconia materials were calcined at $923 \mathrm{~K}$ and are designated as "0.5MnSZ", "2.0MnSZ", "0.5FeSZ", and "2.0FeSZ", depending on promoter type and content. One promoted sample, containing $2.0 \mathrm{wt} \%$ manganese, was calcined at $823 \mathrm{~K}$ to investigate the effect of the calcination temperature and was designated "2.0MnSZ550".

\subsection{Milling and Storage}

Milling was performed in a vibrating mill (PerkinElmer) using $1.5 \mathrm{ml}$ stainless steel capsules, a single ball (d $=3 \mathrm{~mm}$ ), and $300 \mathrm{mg}$ of sample. The maximum interval was $30 \mathrm{~s}$; longer milling times were achieved by consecutive intervals.

Immediately after calcination, catalysts were stored in three different environments with various oxygen and water vapor partial pressures: (i) in vials in a laboratory cupboard, (ii) in open dishes under "tropical" conditions in air saturated with water vapor at $313 \mathrm{~K}$, (iii) in screw-cap 
vials in the dry argon atmosphere of a glovebox, with the $\mathrm{H}_{2} \mathrm{O}$ level $<1$ ppm and the $\mathrm{O}_{2}$ level $\leq 8$ ppm.

\subsection{Characterization}

Surface areas were measured by $\mathrm{N}_{2}$ adsorption and analysis by the BET method using a Quantasorb Junior or an Autosorb-6 apparatus. Samples were outgassed in vacuo at $473 \mathrm{~K}$ for $16 \mathrm{~h}$ before the adsorption.

X-ray diffractograms were recorded using STOESTADI-P diffractometers in Debye-Scherrer geometry with $\mathrm{Cu} \mathrm{K} \alpha$ radiation, primary germanium monochromator, and a linear position-sensitive detector (PSD, internal resolution $2 \Theta=0.01^{\circ}$ ). The powders were mixed $1: 1$ by weight with sieved $\alpha-\mathrm{Al}_{2} \mathrm{O}_{3}$ through gentle shaking and embedded in $\mathrm{X}$ ray amorphous grease. Samples aged in humid atmosphere did not mix properly. The resulting diffractograms were normalized to the intensity of the 113 reflection of corundum at $43.3^{\circ}$. The phase composition of zirconia in the catalysts was then determined by fitting the diffractograms using PowderCell v2.4 by Kraus and Nolze [39]. First, only the peaks of the standard were fit with a Gaussian line profile to the structure of corundum (ICSD 31548 [40]) excluding the $2 \Theta$ regions with many reflections of $\mathrm{ZrO}_{2}$ $\left(<15^{\circ}, 26^{\circ}-34^{\circ}, 47^{\circ}-52^{\circ}, 58^{\circ}-65^{\circ}, 79^{\circ}-87^{\circ}\right)$ to obtain the zeroshift; then the lattice parameters and scaling factors for monoclinic $\left(\mathrm{m}-\mathrm{ZrO}_{2}\right)$ and tetragonal zirconia $\left(\mathrm{t}-\mathrm{ZrO}_{2}\right)$ were determined by fitting with a Lorentzian line profile to the structures of $\mathrm{m}-\mathrm{ZrO}_{2}$ (ICSD 18190) and $\mathrm{t}-\mathrm{ZrO}_{2}$ (ICSC 68589). Normalization in the PowderCell program was set to $I^{\prime}=I / V^{2}$. The scaling factors give information about the fraction of the different components in the diffractogram. In order to relate the scaling factors to the masses of internal standard, $\alpha-\mathrm{Al}_{2} \mathrm{O}_{3}$, and crystalline zirconia, a series of calibration mixtures of crystalline $\mathrm{m}-\mathrm{ZrO}_{2}$ and the $\alpha-\mathrm{Al}_{2} \mathrm{O}_{3}$ internal standard were measured. Mass absorption coefficients of the $\mathrm{m}-\mathrm{ZrO}_{2}\left(\mu_{\mathrm{Zr}}=1.2068\right)$ and the alumina $\left(\mu_{A}=\right.$ 0.7763 ) were determined from a fit of the known mass fraction, $c_{m}$, with the scaling factor determined by PowderCell $\left(c_{\mathrm{Zr}}^{P C}\right)$. The crystalline mass fraction of $\mathrm{ZrO}_{2}$ in the samples was then calculated using the mass absorption coefficients and Klug's equation:

$$
c_{\mathrm{Zr}}=\frac{c_{\mathrm{Zr}}^{P C} \cdot \mu_{\mathrm{Zr}}}{c_{\mathrm{Zr}}^{P C} \cdot\left(\mu_{\mathrm{Zr}}-\mu_{A}\right)+\mu_{A}}
$$

Amorphous material was assumed to be present when the analysis yielded a fraction of alumina exceeding $50 \%$.

X-ray absorption spectroscopy (XAS) on the Mn or Fe K-edge was conducted in fluorescence mode at the Hamburg Synchrotron Radiation Laboratory (HASYLAB) beamline E4. All spectra were energy calibrated by comparison with the spectrum of a simultaneously measured metal foil. The first inflection point in this reference spectrum was set to the $\mathrm{Mn}(6539 \mathrm{keV})$ or $\mathrm{Fe}(7112 \mathrm{eV}) \mathrm{K}$ edge.

Thermogravimetry (TG) and differential scanning calorimetry (DSC) were performed in a STA 499 C instrument (Netzsch) with on-line MS (Pfeiffer, QMS 200) and OmniStar ${ }^{\circledR}$ software. Samples were heated in $20 \mathrm{ml} \mathrm{min}^{-1}$ argon flow to $1373 \mathrm{~K}$, held at this temperature for $30 \mathrm{~min}$, and then cooled to $473 \mathrm{~K}$. The nominal heating and cooling rate was $10 \mathrm{~K} \mathrm{~min}^{-1}$.

Diffuse reflectance Fourier transform IR spectroscopy (DRIFTS) was performed with a Bruker ifs66 FTIR spectrometer equipped with a Graseby-Specac "Selector" diffuse reflection accessory and an "Environmental chamber" [41].

\subsection{Catalytic Tests}

Isomerization of $n$-butane to isobutane was conducted at atmospheric pressure in fixed bed flow reactors. One apparatus consisted of three U-shaped reactors (made from glass, $d_{\text {in }}=10 \mathrm{~mm}$ ), operated in parallel using a catalyst mass of $200 \mathrm{mg}$ per reactor, with analysis by on-line gas chromatography (GC) and thermal conductivity detection (Varian Micro-GC CP-4900). Alternatively, catalytic reactions were conducted in a DRIFTS cell [41], using a catalyst mass of about $160 \mathrm{mg}$ and on-line GC with flame ionization detection (Varian CP-3800 with a Chrompack SilicaPLOT capillary column, $\mathrm{d}_{\mathrm{in}}=0.32 \mathrm{~mm}$, length $60 \mathrm{~m}$, film thickness $4 \mu \mathrm{m}$ ). $\mathrm{N}_{2}$ (Linde or Westfalen, 99.999\%) was purified with Oxysorb ${ }^{\circledR}$ and Hydrosorb ${ }^{\circledR}$ cartridges (Messer Griesheim). The same cylinder of a $5 \%$ butane in $\mathrm{N}_{2}$ mixture (Linde) with a purity of $99.95 \%$ was used for all aging experiments to exclude scattering of catalytic data as a result of varying impurity levels.

Catalysts were activated and adjusted to the same level of hydration by a pretreatment in inert gas. Specifically, the materials were heated in a flow of $40-48 \mathrm{ml} \mathrm{min}^{-1}$ $\mathrm{N}_{2}$ at a rate of $25-29 \mathrm{~K} \mathrm{~min}^{-1}$ to a temperature of $723 \mathrm{~K}$ (in the reactor) or $773 \mathrm{~K}$ (in the DRIFTS cell), held at this temperature for $30 \mathrm{~min}$, and then cooled to reaction temperature. Isomerization was performed at $373 \mathrm{~K}$ for SZ and $323 \mathrm{~K}$ for promoted SZ feeding a $1 \mathrm{vol} \% n$-butane in $\mathrm{N}_{2}$ mixture with a flow rate of $25-30 \mathrm{ml} \mathrm{min}{ }^{-1}$. The amount of isobutane, the only detected impurity in the $n$-butane mixture, was subtracted from the isobutane concentration in the effluent stream. Conversions did not exceed $10 \%$, thus being far from equilibrium.

\section{Results}

\subsection{Properties of calcined materials}

$\mathrm{Z}$ and SZ, calcined at $823 \mathrm{~K}$, exhibited surface areas of $80 \mathrm{~m}^{2} \mathrm{~g}^{-1}$ and $130-140 \mathrm{~m}^{2} \mathrm{~g}^{-1}$, respectively. Surface ar 


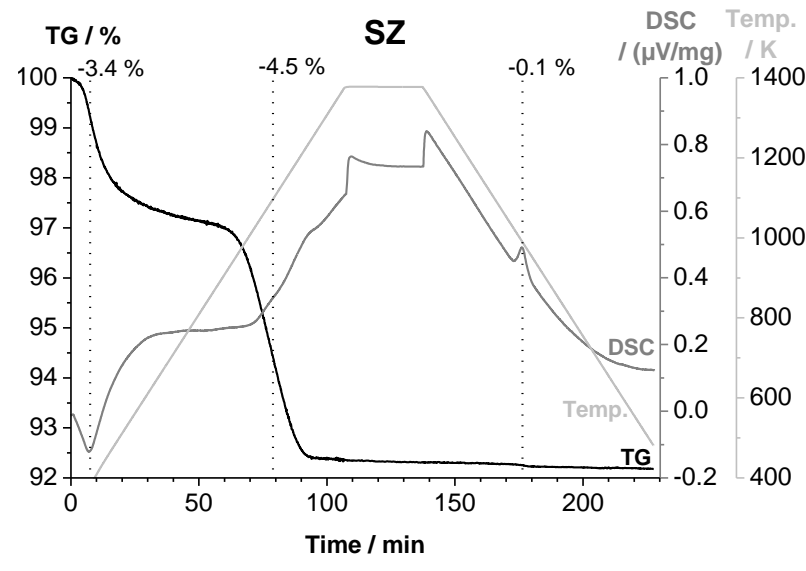

Fig. 1: Thermal analysis of SZ showing the TG and DSC curves as well as the temperature profile during the experiment.

eas of promoted samples were $110-115 \mathrm{~m}^{2} \mathrm{~g}^{-1}$. According to analysis with the BJH method, all samples had pores in the $2-3 \mathrm{~nm}$ range. Diffractograms indicated a mixture of $\mathrm{m}$ $\mathrm{ZrO}_{2}$ and $\mathrm{t}-\mathrm{ZrO}_{2}$ for $\mathrm{Z}$ calcined at $823 \mathrm{~K}$, with the fraction of $\mathrm{m}-\mathrm{ZrO}_{2}$ being $75-80 \mathrm{wt} \%$. Within the detection limit of about $5 \mathrm{wt} \%$, SZ consisted solely of the tetragonal phase. Traces of monoclinic zirconia were present in some samples with a promoter content of $0.5 \mathrm{wt} \%$ after calcination at a temperature of $923 \mathrm{~K}$. A purely tetragonal material was obtained at a promoter content of $2.0 \mathrm{wt} \%$. A significant fraction, possibly as much as one third, of the material in the calcined samples was X-ray amorphous.

\subsection{Thermal stability}

The TG profiles of sulfate-containing samples were characterized by continuous weight loss up to the maximum temperature. Three distinct steps of weight loss were observed during the temperature program: (i) an endothermic loss of 2.2-4.6 wt\% at about $370 \mathrm{~K}$, (ii) a nearly heatneutral loss of 3.9-4.6 wt\% at about $1080 \mathrm{~K}$, and (iii) a very small exothermic weight loss of only about $0.1-0.2$ wt $\%$. The third weight loss occurred for SZ during cooling at $980 \mathrm{~K}$ (Figure 1). Promoters shifted the third event to an earlier time in the temperature program: to the beginning of the isothermal segment for $0.5 \mathrm{MnSZ}$ and $2.0 \mathrm{FeSZ}$, and to $1200 \mathrm{~K}$ during the heating ramp for 2.0MnSZ. In Figure 2, the times and temperatures of the third weight loss are summarized for promoted and unpromoted sulfated zirconia materials.

Selected masses measured during the TG experiment are shown in Figure 3. During the first distinct step in weight loss, $\mathrm{H}_{2} \mathrm{O}$ evolved ( $\mathrm{m} / \mathrm{e} 18-\mathrm{H}_{2} \mathrm{O}^{+}, \mathrm{m} / \mathrm{e} 17-\mathrm{OH}^{+}$, $\left.\mathrm{m} / \mathrm{e} 16-\mathrm{O}^{+}\right)$. The detection of $\mathrm{O}_{2}\left(\mathrm{~m} / \mathrm{e} \mathrm{32}, 34-\mathrm{O}_{2}^{+}, \mathrm{m} / \mathrm{e}\right.$ $\left.16,18-\mathrm{O}^{+}\right)$and $\mathrm{H}_{2}\left(\mathrm{~m} / \mathrm{e} 2-\mathrm{H}_{2}^{+}\right)$is an artifact generated by water reacting in the mass spectrometer. After this event, the weight decreased further. $\mathrm{CO}_{2}(\mathrm{~m} / \mathrm{e} 44)$ desorbed from the catalysts at a nearly constant rate, resulting in a

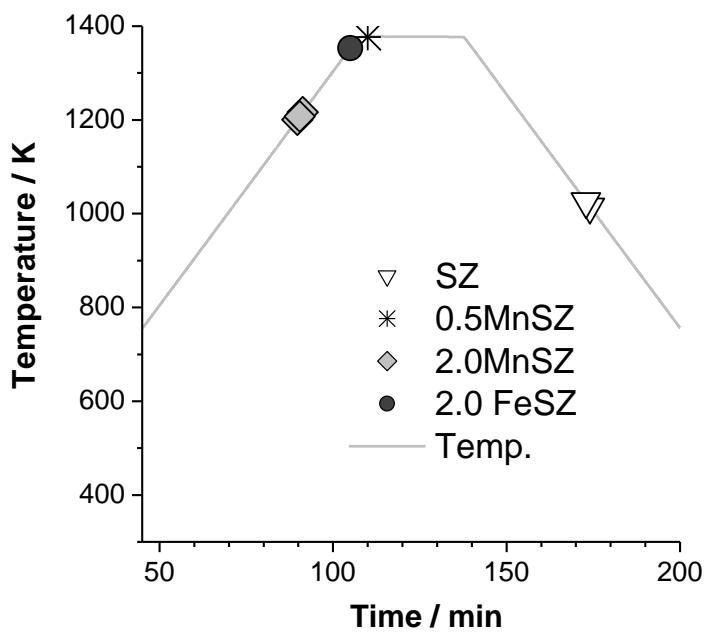

Fig. 2: Time and temperature of the third weight loss for various sulfated zirconia catalysts.

a)

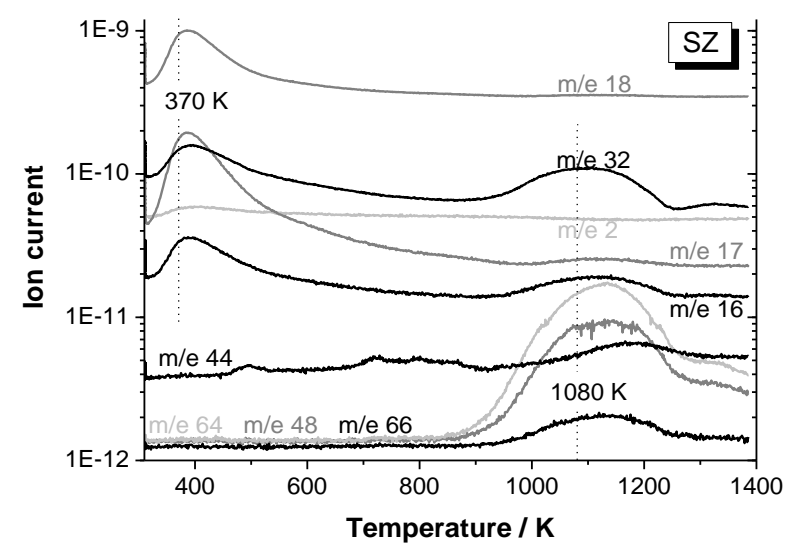

b)

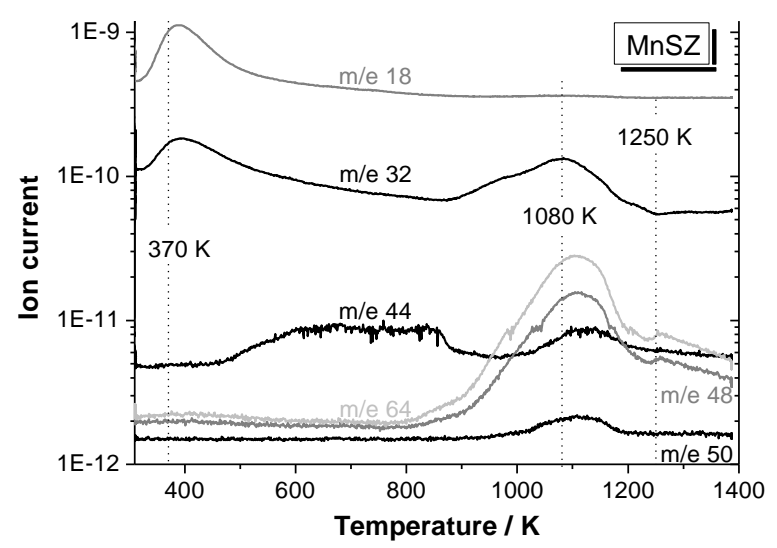

Fig. 3: Evolution of gases observed by mass spectrometry during the heating ramp of thermal analysis of a) SZ and b) $2.0 \mathrm{MnSZ}$. Temperatures in the figure mark steps in weight losses. 
Table 1 Thermogravimetry data of calcined catalysts

\begin{tabular}{lll}
\hline Sample & $\begin{array}{l}\text { 2nd weight loss } \\
\left(\mathrm{SO}_{2}+\mathrm{O}_{2}\right)(\mathrm{wt} \%)\end{array}$ & $\begin{array}{l}\text { 3rd weight loss } \\
\left(\mathrm{SO}_{2}\right)(\mathrm{wt} \%)\end{array}$ \\
\hline $\mathrm{SZ}$ & 4.52 & 0.058 \\
$0.5 \mathrm{MnSZ}$ & 4.03 & 0.125 \\
$2.0 \mathrm{MnSZ}$ & 4.20 & 0.157 \\
$2.0 \mathrm{MnSZ} 550$ & 4.33 & 0.168 \\
$0.5 \mathrm{FeSZ}$ & 4.04 & 0.068 \\
$2.0 \mathrm{FeSZ}$ & 3.96 & 0.094 \\
\hline
\end{tabular}

continuous weight loss. During the second distinct weight loss $\mathrm{SO}_{2}\left(\mathrm{~m} / \mathrm{e}\right.$ 64, 66- $\left.\mathrm{SO}_{2}^{+}, \mathrm{m} / \mathrm{e} 48,50-\mathrm{SO}^{+}\right)$and $\mathrm{O}_{2}$ $\left(\mathrm{m} / \mathrm{e}\right.$ 32, 16) evolved; the ratio of $\mathrm{SO}_{2}$ and $\mathrm{O}_{2}$ is ca. 2:1. Thus, the weight loss at about $1000 \mathrm{~K}$ is attributed to the decomposition of sulfate species. The third distinct weight loss coincided with the detection of $\mathrm{SO}_{2}$ in the off-gas (but no $\mathrm{O}_{2}$ evolved).

The second weight loss was larger for SZ and 2.0MnSZ550 (both calcined at $823 \mathrm{~K}$ ) than for promoted samples (calcined at $923 \mathrm{~K}$ ); the third weight loss was about twice as large for promoted samples as for unpromoted SZ and larger for manganese-promoted in comparison to iron-promoted samples (Table 1).

Most of the samples were completely monoclinic after the thermal analysis experiment; the $0.5 \mathrm{MnSZ}$ sample produced an additional reflection consistent with a trace of tetragonal or cubic zirconia. In the diffractogram of 2.0FeSZ an additional reflection was visible at an angle of $33.1^{\circ}$ (not shown), which can be assigned to the most intense reflection of $\alpha-\mathrm{Fe}_{2} \mathrm{O}_{3}$, the (104) reflection.

\subsection{Long term stability during storage in various atmospheres}

SZ remained white during storage. The aged MnSZ samples were gray and increasingly darker in the order laboratory $\ll$ glovebox $<$ tropical. BET surface areas were constant during 7 months. The water content was estimated by comparing the weight of each sample before and after the outgassing for the BET measurement. The weight loss increased with the water content of the storage atmosphere: glovebox < laboratory < tropical (Table 2).

This observation is supported by IR spectroscopy, which delivers information about the degree of hydroxylation and hydration. DRIFT spectra of $2.0 \mathrm{MnSZ}$ after 7 months aging in dry (glovebox) and wet (tropical) atmosphere are compared in Figure 4. The range $3600-3000 \mathrm{~cm}^{-1}$ is typical for $\mathrm{O}-\mathrm{H}$ stretching vibrations, the $\mathrm{OH}$ bending mode of adsorbed water is located around $1600 \mathrm{~cm}^{-1}$, the combination of stretching and bending vibrations of water gives rise to a band around $5200 \mathrm{~cm}^{-1}$. Before activation at elevated temperature, the band area of the water deformation band centered at $1600 \mathrm{~cm}^{-1}$ was ca. 2.5 times larger in the spectrum of $2.0 \mathrm{MnSZ}$ stored under tropical conditions than in the spectrum of $2.0 \mathrm{MnSZ}$ stored in the glovebox, a)

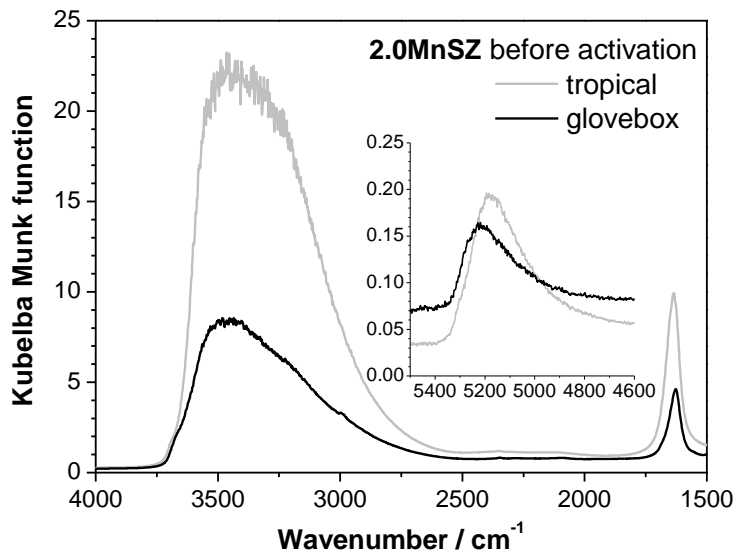

b)

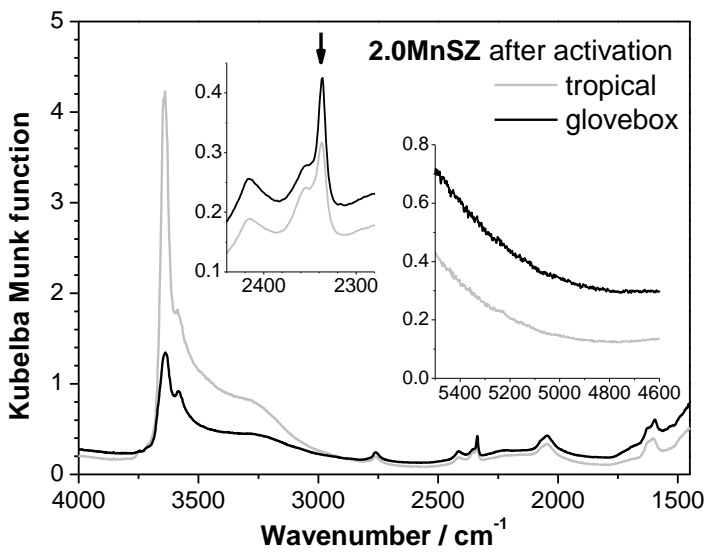

Fig. 4: DRIFT spectra of 2.0MnSZ aged for 7 months before (a) and directly after (b) activation for $30 \mathrm{~min}$ at $773 \mathrm{~K}$ (ramp $25 \mathrm{~K}$ $\min ^{-1}$ ) in $48 \mathrm{ml} \mathrm{min}^{-1} \mathrm{~N}_{2}$

indicating a significantly higher water content of the sample stored in a humid environment (Figure 4a). This result correlates well with the weight losses observed during outgassing of these two samples, which form a ratio of 2.4 (Table 2). After the heat treatment, most of the water was removed, and the combination mode centered at $5220 \mathrm{~cm}^{-1}$ (glovebox) or $5180 \mathrm{~cm}^{-1}$ (tropical) disappeared (Figure 4b). The bands observed around $1600 \mathrm{~cm}^{-1}$ possessed nearly the same, very small integral intensity for both samples. However, the amount of $\mathrm{OH}$ groups present after activation was larger for $2.0 \mathrm{MnSZ}$ stored under tropical conditions than for $2.0 \mathrm{MnSZ}$ stored in a glovebox. In turn, the intensity of the band at $2336 \mathrm{~cm}^{-1}$, which is the stretching vibration of adsorbed $\mathrm{N}_{2}$ (from the activation atmosphere), was larger for 2.0MnSZ stored in the glovebox. The DRIFT spectra of 2.0MnSZ aged in the laboratory did not change significantly over 7 months; after 40 months a higher concentration of $\mathrm{OH}$ groups was present before activation than on the fresh sample.

Already after two months storing under tropical conditions monoclinic reflections appeared in the diffractograms of SZ (Figure 5). The fraction of $\mathrm{m}-\mathrm{ZrO}_{2}$ increased with longer aging times and reached about $10 \mathrm{wt} \%$ after 6 
Table 2 Weight loss during outgassing ( $16 \mathrm{~h}, 473 \mathrm{~K}$ ) prior to BET measurements

\begin{tabular}{llllll}
\hline Sample & Aging time (months) & BET surface area $\left(\mathrm{m}^{2} \mathrm{~g}^{-1}\right)$ & & \multicolumn{2}{l}{ Weight loss (wt $\%)$} \\
\cline { 4 - 6 } & & Fresh & Glovebox & Laboratory & Tropical \\
\hline $\mathrm{SZ}$ & 2 & 147 & 3.12 & 5.91 & 11.55 \\
$2.0 \mathrm{MnSZ}$ & 6.5 & 119 & 4.91 & 7.07 & 11.63 \\
\hline
\end{tabular}

Samples stored under specified conditions (glovebox, laboratory, tropical)

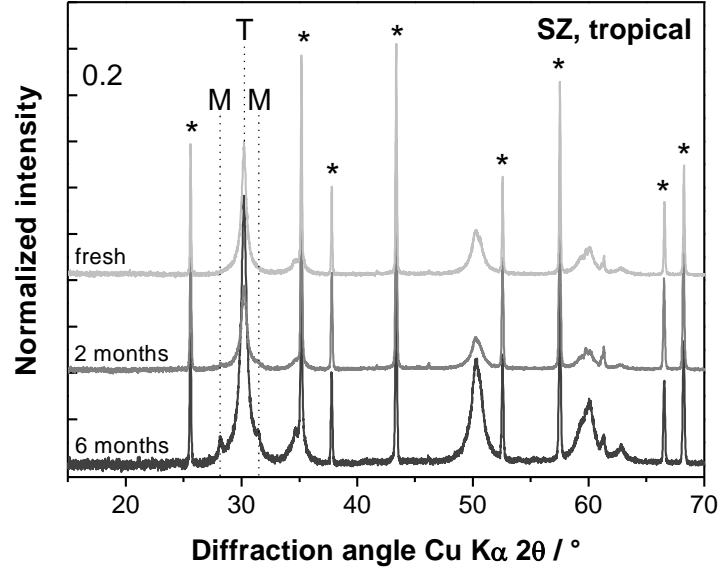

Fig. 5: X-ray powder diffractograms of $\mathrm{SZ}$ aged under tropical conditions. Asterisks indicate internal standard $\alpha-\mathrm{Al}_{2} \mathrm{O}_{3}$.

months (Table 3). When aged in the glovebox, SZ was still tetragonal after two months; after six months, one of the main reflections of monoclinic zirconia appeared. SZ aged in the laboratory was most stable; after nine months only tetragonal reflections were measured. The phase composition of $2.0 \mathrm{MnSZ}$ did not change measurably within six months, independent of the storage atmosphere.

\subsection{Effect of storage conditions on catalytic per- formance}

Figure 6 shows the isomerization rate at $373 \mathrm{~K}$ of fresh and 6 months aged SZ. After calcination, the maximum rate of about $23 \mu \mathrm{mol} \mathrm{g}{ }^{-1} \mathrm{~h}^{-1}$ was reached after ca. $3 \mathrm{~h}$ (Table 3). After six months storage in the laboratory, the maximum rate, reached after $17 \mathrm{~h}$ on stream, was only about $10 \mu \mathrm{mol} \mathrm{g}^{-1} \mathrm{~h}^{-1}$. Storage under tropical conditions resulted in a decrease of the maximum rate to about $3 \mu \mathrm{mol} \mathrm{g}{ }^{-1} \mathrm{~h}^{-1}$. SZ stored in the glovebox for six months had a local maximum in rate after $1 \mathrm{~h}$, then the rate increased again and after $25 \mathrm{~h}$ it was as high as that of the fresh catalyst. This behavior was reproduced with a second sample. During the observation span of $25 \mathrm{~h}$, unpromoted SZ did not deactivate.

The activity profile of $2.0 \mathrm{MnSZ}$ kept in the laboratory did not change significantly during half a year, whereas the other two storage environments affected the

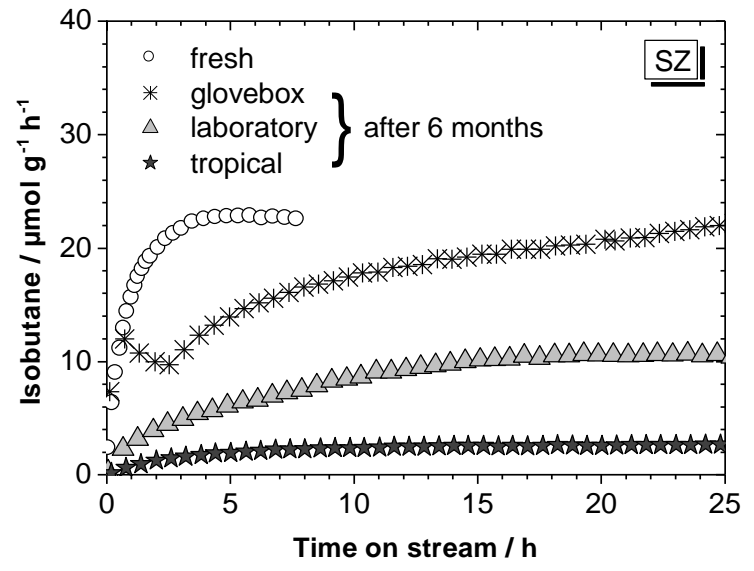

Fig. 6: Rate of isobutane formation on SZ stored under three different conditions up to 6 months. Catalytic test performed in a Ushaped tubular reactor; catalyst mass $200 \mathrm{mg}$. Activation: $40 \mathrm{ml}$ $\min ^{-1} \mathrm{~N}_{2}, 30 \mathrm{~min}$ at $723 \mathrm{~K}$; reaction temperature $373 \mathrm{~K}$, feed 1 vol\% $n$-butane in $\mathrm{N}_{2}$ at atmospheric pressure; total flow $25 \mathrm{ml}$ $\min ^{-1}$.

catalytic performance (Table 3). The sample stored under tropical conditions exhibited a decrease in the maximum rate after one week, but no significant changes during further aging (Figure 7a). Drastic changes were observed in the isomerization activity of $2.0 \mathrm{MnSZ}$ stored in the glovebox (Figure 7b): The maximum rate decreased from ca. 250 to $150 \mu \mathrm{mol} \mathrm{g}^{-1} \mathrm{~h}^{-1}$ after one month and to only $24 \mu \mathrm{mol} \mathrm{g}^{-1} \mathrm{~h}^{-1}$ after half a year; concomitantly the maximum shifted from about 1 to $16 \mathrm{~h}$ time on stream.

\subsection{Effects of milling}

Surface areas were measured after milling for various times in the vibrating mill and after catalytic experiments. Variations in surface area did not exceed $\pm 10 \%$. There was a trend toward higher surface area after milling; no significant effect on the pore size distribution was observed.

The relative amount of $\mathrm{m}-\mathrm{ZrO}_{2}$ to $\mathrm{t}-\mathrm{ZrO}_{2}$ increased during milling for all samples, and more so at longer milling times. In the absence of sulfate and promoters, the fraction of $\mathrm{m}-\mathrm{ZrO}_{2}$ increased from about $75 \mathrm{wt} \%$ in the calcined sample to $87 \mathrm{wt} \%$ after $10 \mathrm{~min}$. The fraction of $\mathrm{m}-$ $\mathrm{ZrO}_{2}$ in $\mathrm{SZ}$ was about $30 \mathrm{wt} \%$ after $10 \mathrm{~min}$ of milling. Promoting SZ with manganese or iron did not prevent the 
Table 3 Effects of aging on sulfated zirconia materials

\begin{tabular}{|c|c|c|c|c|c|}
\hline Sample & Atmosphere & $\begin{array}{l}\text { Time } \\
\text { (months) }\end{array}$ & $\begin{array}{l}\text { Tetragonal } \\
\text { phase }(\text { wt } \%)^{\mathrm{a}}\end{array}$ & $\begin{array}{l}\text { Maximum } \\
\text { isomerization rate } \\
\left(\mu \mathrm{mol} \mathrm{g} \mathrm{g}^{-1} \mathrm{~h}^{-1}\right)^{\mathrm{b}}\end{array}$ & $\begin{array}{l}\text { Time to maximum } \\
\text { rate (h) }\end{array}$ \\
\hline \multirow[t]{9}{*}{ SZ } & \multirow[t]{3}{*}{ Glove box } & 0 & 100 & \multirow[t]{2}{*}{23} & \multirow[t]{2}{*}{3} \\
\hline & & 1 & 100 & & \\
\hline & & 6 & $100^{\circ}$ & 23 & $25^{\mathrm{d}}$ \\
\hline & \multirow[t]{3}{*}{ Laboratory } & 0 & 100 & \multirow[t]{2}{*}{23} & \multirow[t]{2}{*}{3} \\
\hline & & 1 & 100 & & \\
\hline & & 6 & 100 & 10 & 17 \\
\hline & \multirow[t]{3}{*}{ Tropical } & 0 & 100 & \multirow[t]{2}{*}{23} & \multirow[t]{3}{*}{3} \\
\hline & & 1 & 95 & & \\
\hline & & 6 & 90 & 3 & \\
\hline \multirow[t]{9}{*}{ 2.0MnSZ } & \multirow[t]{3}{*}{ Glove box } & 0 & 100 & 250 & 1 \\
\hline & & 1 & 100 & 150 & 2 \\
\hline & & 6 & 100 & 24 & 16 \\
\hline & \multirow[t]{3}{*}{ Laboratory } & 0 & 100 & 250 & 0.8 \\
\hline & & 1 & 100 & 230 & 0.8 \\
\hline & & 6 & 100 & 230 & 0.6 \\
\hline & \multirow[t]{3}{*}{ Tropical } & 0 & 100 & 270 & 1 \\
\hline & & 1 & 100 & 220 & 0.5 \\
\hline & & 6 & 100 & 190 & 0.5 \\
\hline
\end{tabular}

a)

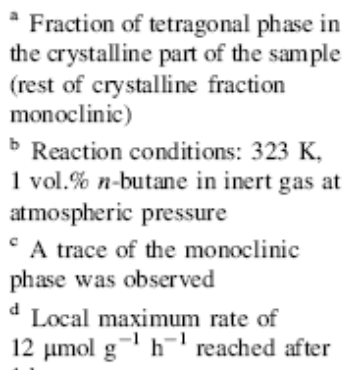

a Fraction of tetragonal phase in the crystalline part of the sample (rest of crystalline fraction monoclinic)

${ }^{b}$ Reaction conditions: $323 \mathrm{~K}$, $1 \mathrm{vol} \% n$-butane in inert gas at atmospheric pressure

c A trace of the monoclinic phase was observed

${ }^{\mathrm{d}}$ Local maximum rate of $12 \mu \mathrm{mol} \mathrm{g}{ }^{-1} \mathrm{~h}^{-1}$ reached after

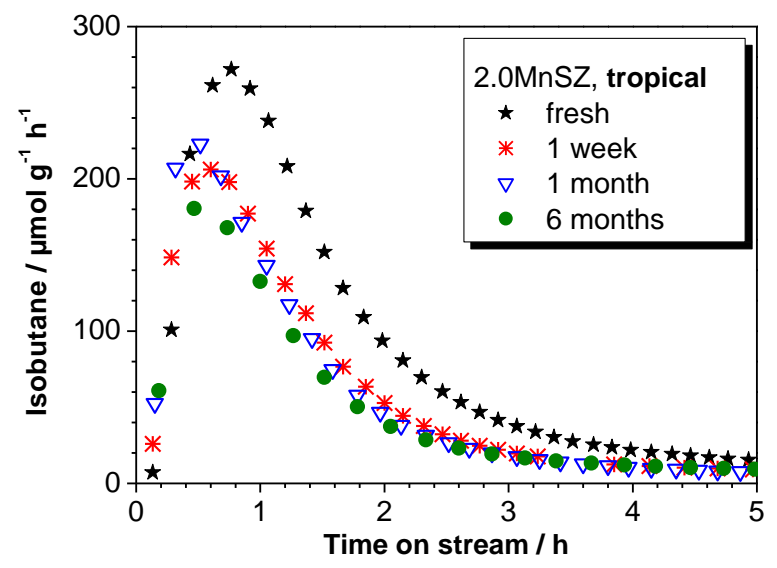

b)

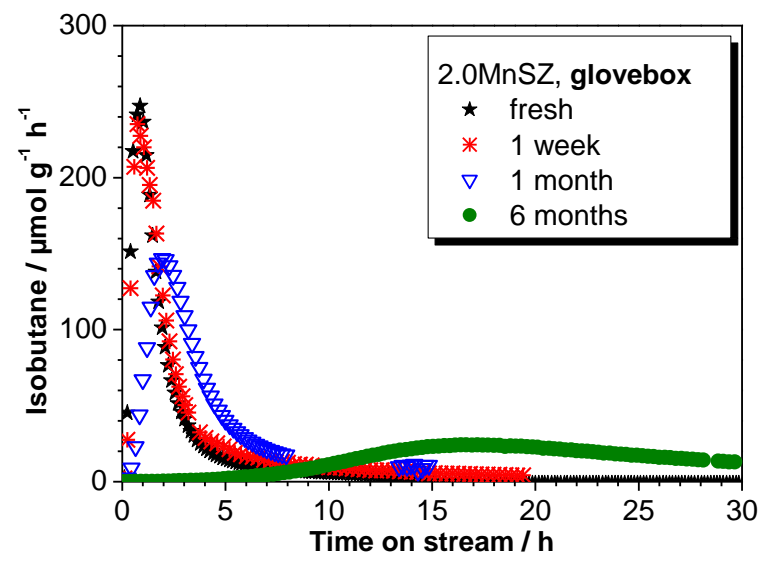

Fig. 7: Rate of isobutane formation on 2.0MnSZ stored for up to 6 months in tropical conditions (a) or in a glovebox (b). Catalytic test performed in a U-shaped tubular reactor; catalyst mass $200 \mathrm{mg}$. Activation: $40 \mathrm{ml} \mathrm{min} \mathrm{m}^{-1} \mathrm{~N}_{2}, 30 \mathrm{~min}$ at $723 \mathrm{~K}$; reaction temperature $323 \mathrm{~K}$; feed 1 vol\% $n$-butane in $\mathrm{N}_{2}$ at atmospheric pressure; total flow $25 \mathrm{ml} \mathrm{min}^{-1}$ phase transformation during milling, as the data in Table 4 show. After $10 \mathrm{~min}$ of milling, the fraction of $\mathrm{m}-\mathrm{ZrO}_{2}$ reached $44-53 \mathrm{wt} \%$ in the samples with $0.5 \mathrm{wt} \%$ promoter. About $28 \mathrm{wt} \% \mathrm{~m}-\mathrm{ZrO}_{2}$ was present in $2.0 \mathrm{FeSZ}$ after 10 min, whereas only $5 \mathrm{wt} \%$ were detected in $2.0 \mathrm{MnSZ}$.

The average valence of manganese can be determined from the Mn K-edge shift of the sample relative to the edge position of a manganese foil $(6539 \mathrm{keV})$; the shift is interpreted on the basis of a calibration using $\mathrm{MnO}$ and $\mathrm{Mn}_{2} \mathrm{O}_{3}$ as references with known oxidation states $[42,43]$. The edge positions, edge shifts, and resulting values for the average manganese valence of $2.0 \mathrm{MnSZ}$ and $0.5 \mathrm{MnSZ}$ are listed in Table 5. Only changes in the valence larger than 0.03 are significant. Milling slightly reduced manganese in 2.0MnSZ, whereas the average valence of manganese in $0.5 \mathrm{MnSZ}$ was lower than in $2.0 \mathrm{MnSZ}$ and unaffected by milling.

TG showed that the second weight loss at about $1000 \mathrm{~K}$ is $4.6 \mathrm{wt} \%$ for unmilled SZ and $4.2 \mathrm{wt} \%$ for $10 \mathrm{~min}$ milled SZ. The respective weight loss for unmilled $0.5 \mathrm{FeSZ}$ amounted to $4.0 \mathrm{wt} \%$ and decreased to $3.9 \mathrm{wt} \%$ for 5 or 10 min milled $0.5 \mathrm{FeSZ}$. The high temperature stable sulfate species, which produces the third weight loss, was still present after milling. Because this species constitutes only a small fraction (1-5\%) of the total sulfate content, an influence of milling on its amount was not measurable. DRIFT spectra were recorded after activation at $773 \mathrm{~K}$ to further investigate the sulfate species, specifically a band at $2763 \mathrm{~cm}^{-1}$, which represents an overtone of a $\mathrm{S}=\mathrm{O}$ vibration at about $1400 \mathrm{~cm}^{-1}$. Figure 8 shows a series of spectra of $0.5 \mathrm{MnSZ}$, which show that the overtone vibrations become less intense with increasing milling time. This trend was also observed for other manganese-promoted catalysts. Iron-promoted catalysts were characterized by a similar decline but the data showed considerable variation (Table 4). 
Table 4 Effects of milling on promoted sulfated zirconia materials a Fraction of tetragonal phase in the crystalline part of the sample (rest of crystalline fraction monoclinic)

${ }^{b}$ From DRIFT spectra recorded after activation at $723 \mathrm{~K}$ in inert gas stream

c Reaction conditions: $323 \mathrm{~K}$, 1 vol. $\% n$-butane in inert gas at atmospheric pressure

\begin{tabular}{lcccc}
\hline Sample & $\begin{array}{l}\text { Milling time } \\
(\mathrm{min})\end{array}$ & $\begin{array}{l}\text { Tetragonal } \\
\text { phase }(\mathrm{wt} \%)^{\mathrm{a}}\end{array}$ & $\begin{array}{l}\text { Relative area of band } \\
\text { at } 2755-2770 \mathrm{~cm}^{-1}(\%)^{\mathrm{b}}\end{array}$ & $\begin{array}{l}\text { Maximum isomerization } \\
\text { rate }\left(\mu \mathrm{mol} \mathrm{g} \mathrm{g}^{-1} \mathrm{~h}^{-1}\right)^{\mathrm{c}}\end{array}$ \\
\hline 0.5MnSZ & 0 & 99 & 100 & 7.3 \\
& 5 & 63 & 25 & 3.8 \\
& 10 & 47 & 20 & 1.5 \\
2.0MnSZ & 0 & 100 & 100 & 196 \\
& 5 & 95 & 70 & 128 \\
& 10 & 95 & & 93 \\
$0.5 \mathrm{FeSZ}$ & 0 & 100 & 100 & 21 \\
& 5 & 62 & 35 & 0.3 \\
& 10 & 56 & 35 & 0.7 \\
$2.0 \mathrm{FeSZ}$ & 0 & 100 & 100 & 250 \\
& 5 & 83 & 25 & 6 \\
& 10 & 72 & 40 & 9 \\
\hline
\end{tabular}

Table 5 Edge energy, edge shift relative to $\mathrm{Mn}^{0}(6539 \mathrm{keV})$, and average $\mathrm{Mn}$ valence of $\mathrm{MnSZ}$ containing 0.5 or $2.0 \mathrm{wt} \%$ promoter before and after milling for the indicated times

\begin{tabular}{lcll}
\hline Sample & $\begin{array}{l}\text { Milling time } \\
(\mathrm{min})\end{array}$ & $\begin{array}{l}\text { Edge energy } \\
(\mathrm{keV})\end{array}$ & $\begin{array}{l}\text { Average Mn } \\
\text { valence }\end{array}$ \\
\hline $0.5 \mathrm{MnSZ}$ & 0 & 6547.17 & 2.54 \\
& 10 & 6547.20 & 2.55 \\
$2.0 \mathrm{MnSZ}$ & 0 & 6547.60 & 2.65 \\
& 5 & 6547.31 & 2.58 \\
& 10 & 6547.44 & 2.61 \\
\hline
\end{tabular}

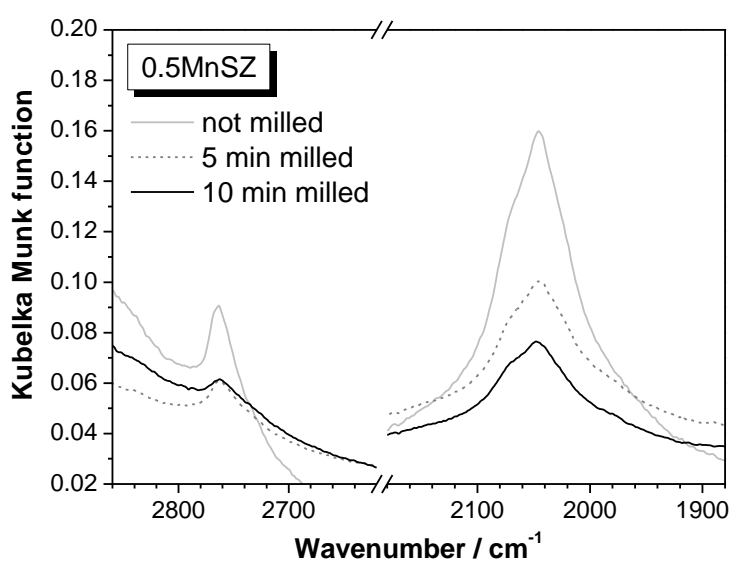

Fig. 8: DRIFT spectra of unmilled and milled $0.5 \mathrm{MnSZ}$ after activation at $773 \mathrm{~K}$; range of $\mathrm{S}=\mathrm{O}$ overtone vibrations shown.

\subsection{Catalytic performance after milling}

The catalytic performance was affected by milling. As published elsewhere [28], the induction period typical of sulfated zirconia materials [24] lasted $10 \mathrm{~h}$ for SZ milled for $10 \mathrm{~min}$ vs. $6 \mathrm{~h}$ for unmilled SZ, and the maximum iso- butane formation rate amounted to only $25 \%$ of the value measured for unmilled SZ under the chosen conditions.

The maximum rate of isomerization was reached very late by $0.5 \mathrm{MnSZ}$, after $19 \mathrm{~h}$ time on stream. The length of the induction period was not significantly affected by milling, but the maximum rate decreased with increasing milling time of 0 , 5, or $10 \mathrm{~min}: 7.3>3.8>$ $1.5 \mu \mathrm{mol} \mathrm{g}^{-1} \mathrm{~h}^{-1}$ (data recorded using DRIFTS cell, see Figure 9a and Table 4).

The maximum rate of isobutane formation attained by $2.0 \mathrm{MnSZ}$ was similarly reduced from 196 to $93 \mu \mathrm{mol} \mathrm{g}{ }^{-1} \mathrm{~h}^{-1}$ by milling (Table 4 ); the long term activity $(>4 \mathrm{~h}$ ) remained unaffected, as can be seen in Figure $9 \mathrm{~b}$. The rates obtained for $2.0 \mathrm{MnSZ}$ in the DRIFTS cell are lower than those measured in the plug flow reactor (Figure 7), as reported before [41].

In Figure 9c, the influence of milling on the isomerization rate achieved by $0.5 \mathrm{FeSZ}$ is presented. Catalysts containing iron show drastic changes in the rate profile after $5 \mathrm{~min}$ milling; the rate maxima of $250 \mu \mathrm{mol} \mathrm{g}{ }^{-1} \mathrm{~h}^{-1}$ (2.0FeSZ) or $21 \mu \mathrm{mol} \mathrm{g}^{-1} \mathrm{~h}^{-1}(0.5 \mathrm{FeSZ})$ were reduced to $6 \mu \mathrm{mol} \mathrm{g}{ }^{-1} \mathrm{~h}^{-1}$ (2.0FeSZ) or $0.3 \mu \mathrm{mol} \mathrm{g}{ }^{-1} \mathrm{~h}^{-1}$ (0.5FeSZ) after 5 min milling. The maxima after milling were lower than the long term rate of the unmilled catalysts, which was $20 \mu \mathrm{mol} \mathrm{g}^{-1} \mathrm{~h}^{-1}$ (2.0FeSZ) or $4 \mu \mathrm{mol} \mathrm{g}^{-1} \mathrm{~h}^{-1}(0.5 \mathrm{FeSZ})$ after $18 \mathrm{~h}$ time on stream.

\section{Discussion}

The results show that zirconia phase changes occur during thermal and mechanical treatments as well as during storage; the discussion thus starts with a brief review of the zirconia phase chemistry. Next, the change of the surface energy through adsorbates and the consequences for the phase stability are elucidated. This discussion is expanded to literature data to demonstrate that such phase behavior is 
a)

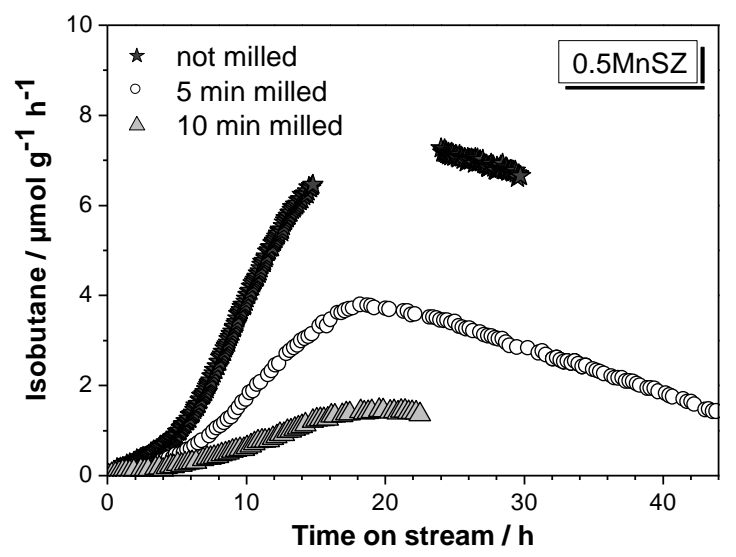

b)

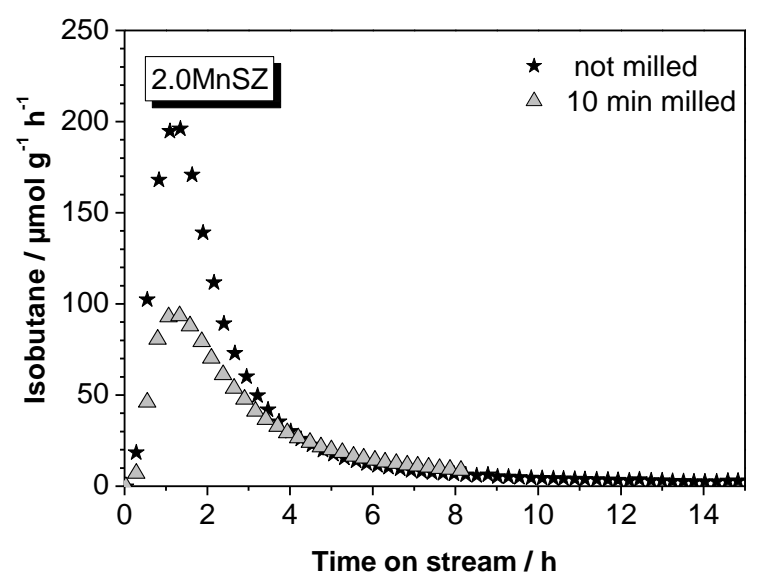

c)

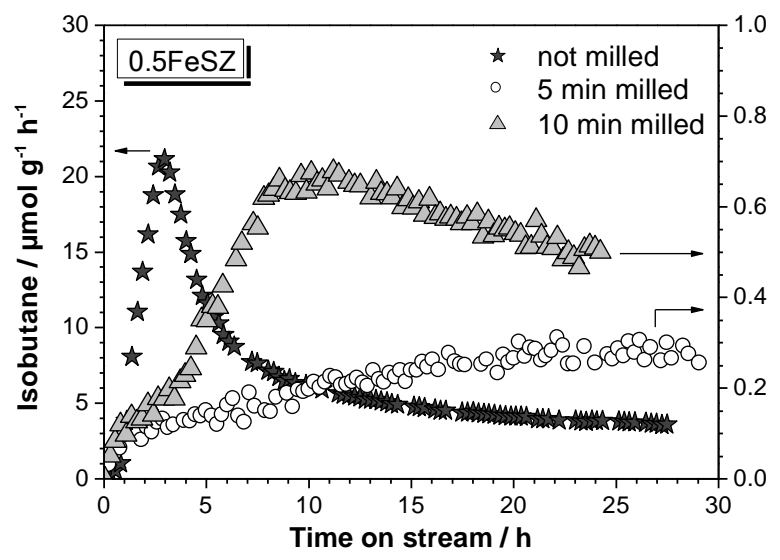

Fig. 9: Rate of isobutane production for $0.5 \mathrm{MnSZ}$ (a), 2.0MnSZ (b) and $0.5 \mathrm{FeSZ}$ (c) before and after milling. Catalysis performed in DRIFTS cell at $323 \mathrm{~K}$ after activation at $773 \mathrm{~K}$; catalyst mass ca. $160 \mathrm{mg}$; reaction temperature $323 \mathrm{~K}$; feed 1 vol\% $n$-butane in $\mathrm{N}_{2}$ at atmospheric pressure; total flow $30 \mathrm{ml} \mathrm{min}^{-1}$.

not unique to sulfated zirconia, and similar phenomena occur with other oxides and other oxoanions. This knowledge provides the background for interpretation of the observed phase composition. The thermal stability of the adsorbates and the consequences for the phase composition are addressed next, followed by discussion of the effects of storage and milling.

\subsection{Zirconia phase chemistry and catalytic activ- ity}

Zirconia exists in three polymorphs with enantiotropic transitions, that is, at certain temperatures the phases can be reversibly transformed. Luo and Stevens [44] report that the monoclinic phase is stable at room temperature, the tetragonal phase is formed at temperatures above $1443 \mathrm{~K}$ and the cubic phase at temperatures above $2643 \mathrm{~K}$, before melting occurs at $2953 \mathrm{~K}$. The tetragonal phase of zirconia can become thermodynamically stable below 1443 $\mathrm{K}$ for crystals smaller than about $30 \mathrm{~nm}$ [8]. This stabilization occurs when the contribution of the surface energy, which is lower for the tetragonal than for the monoclinic phase, prevails over the energy contributions of the bulk crystals, which favor the monoclinic phase at room temperature. This phenomenon of "stability crossover" has been observed for a number of oxides, among them $\gamma-\mathrm{Al}_{2} \mathrm{O}_{3}$ and $\alpha-\mathrm{Al}_{2} \mathrm{O}_{3}$ [10], the anatase and rutile modifications of $\mathrm{TiO}_{2}$ [45], and $\mathrm{ZnO}$ nanoparticles of various morphologies [45]. The influence of morphology, a combination of tracht (i.e., the arrangement of exposed planes) and habit (i.e., the relative area contributions of these planes) of the crystal, on the phase stability implies that general statements on the surface energy of various polymorphs must be regarded with some caution; each plane of each polymorph is characterized by an individual surface energy.

Stabilization of the tetragonal phase of zirconia is also possible by introducing oxygen vacancies into the bulk [27 and references therein], which can be achieved by doping with cations of lower valence than +IV; for example, $\mathrm{Y}^{3+}$ is frequently used [46]. The various phases of zirconia are stable in various ranges of oxygen vacancy concentration. Promoter ions such as $\mathrm{Fe}^{3+}$ or $\mathrm{Mn}^{\mathrm{x}+}(\mathrm{x}<4)$ have also been shown to stabilize the high temperature phases of zirconia [47-51]. They are incorporated into the lattice similarly to $\mathrm{Y}^{3+}$, and for charge balance, oxygen vacancies are formed.

The tetragonal phase is presumed to be essential for a highly active sulfated zirconia catalyst [25,52-54]; samples containing a monoclinic fraction are always less active in alkane isomerization than purely tetragonal materials $[26,28]$. However, the tetragonal phase does not guarantee a high activity [55]. The reasons for the superior performance of tetragonal zirconia have not yet been identified, possibly because of a complex interplay between zirconia and sulfate species. Sulfate alters the zirconia surface and strong Lewis acid sites are detected in its presence [56]. In turn, the zirconia surfaces enable a large variety of sulfate structures. Recently, disulfate was proposed to play an essential role in the activation of alkanes [57], and it was found to form on the (101) surface of tetragonal zirconia [29]. However, it is not known whether the tetragonal phase is a prerequisite for disulfate formation or whether 
this species can also form on any surface of the other zirconia polymorphs.

\subsection{Effects of adsorbates on oxide surface energy and reactivity of adsorbates}

The surface energy is modified through any adsorbate as, for example, water or sulfate; and a change in surface energy affects the particle size at which the stability crossover will occur. The effect of water adsorption on the stability of various oxides has been investigated by Navrotsky [45]. Tetragonal crystallites of zirconia are stable at sizes smaller than $34 \pm 5 \mathrm{~nm}$ as long as the surface is dehydrated; whereas the stability range extends only to $28 \pm 6 \mathrm{~nm}$ when the surface is hydrated [61]. Thus, the adsorption of water reduces the difference in surface energy between the tetragonal and the monoclinic phase of zirconia. Similar observations were made for $\gamma-\mathrm{Al}_{2} \mathrm{O}_{3}$ and $\alpha-\mathrm{Al}_{2} \mathrm{O}_{3}, \gamma-\mathrm{Fe}_{2} \mathrm{O}_{3}$ and $\alpha-\mathrm{Fe}_{2} \mathrm{O}_{3}, \gamma-\mathrm{FeOOH}$ and $\alpha-\mathrm{FeOOH}$, and the modifications of $\mathrm{TiO}_{2}$ (brookite, anatase and rutile) [45]. The difference between the surface energies diminishes because the adsorption energy is proportional to the surface energy [10]; this concept was first postulated by Cerofolini [58]. Indeed, differential heats of adsorption of water on tetragonal zirconia reach a maximum of $150 \mathrm{~kJ} \mathrm{~mol}^{-1}$ at low coverages, whereas the heats on monoclinic zirconia can be as high as $275 \mathrm{~kJ} \mathrm{~mol}^{-1}$ [59].

Following the concept of Cerofolini, other molecules should be more strongly bound to monoclinic than to tetragonal zirconia, because of the higher surface energy of the former phase. Consistent with this hypothesis, Pokrovski et al. [60] found that, at the same temperature, much more $\mathrm{CO}$ or $\mathrm{CO}_{2}$ per surface unit area can be chemisorbed on monoclinic than on tetragonal zirconia. More important for the discussion here, $\mathrm{Li}$ et al. [54] detected a significantly higher uptake of $\mathrm{SO}_{3}$ by monoclinic than by tetragonal zirconia at a temperature of $473 \mathrm{~K}$. One may speculate that adsorbed $\mathrm{SO}_{3}$ or sulfate will also reduce the difference in surface energies between the two phases and will, similar to water, diminish the particle size for the stability crossover.

Another implication of the differences in surface energies and the resulting variations in heats of adsorption concerns the reactivity of the formed surface species. For example, the less strongly bound sulfate on the surface of tetragonal zirconia may be more reactive than the more strongly bound sulfate on monoclinic zirconia. Formulating a more general concept for stability crossover materials, the bare surfaces of the phases with low surface energy, which are metastable for extended crystallites but can be stabilized through small particle sizes, should be less reactive than the bare surfaces of the thermodynamically stable bulk phases with high surface energies. In contrast, the reactivity of species deposited on such surfaces may show an opposite trend, for example oxo anions such as sulfate, vanadate, or molybdate should be less strongly bound and thus more reactive on the low surface energy phases. This concept has its limitations, as illustrated by the fact that sulfate fits better on brookite and anatase than on rutile for steric reasons, and hence its reactivity when situated on the phases with the lower surface energy may not be particularly high. Given larger adsorbate structures such as polyoxometallates, the match with the lattice dimensions may become more important. In a detailed picture, the surface energies and dimensions of individual planes would have to be considered.

Previous results show that promoters such as iron or manganese, which are incorporated into the tetragonal phase, enhance the reactivity, specifically, the reducibility and thus the oxidizing power of sulfate [35]. Promoters with a valence lower than + IV enhance the stability of the tetragonal phase because oxygen vacancies are generated. The incorporation of the iron and manganese cations leads to a smaller unit cell size of the tetragonal phase, mostly through reduction of the unit cell constant $c$ [47]. The doping affects the stability in a second way because the reduced unit cell size will affect the surface energy. If the surface energy becomes smaller, then the stability range of the tetragonal phase will extend to even larger crystallite sizes. According to Cerofilini's concept, the sulfate should be less strongly bound when the surface energy is lower, which should alter, specifically enhance, its reactivity.

\subsection{Phase composition of calcined zirconia ma- terials}

The materials in the present contribution were prepared from hydrous zirconia precursors, and crystallization of the various $\mathrm{ZrO}_{2}$ phases occurred during calcination. In accordance with the Ostwald rule, thermal crystallization typically produces first tetragonal particles, which may subsequently transform to monoclinic particles.

Pure zirconia was a mixture of the tetragonal (20-25\%) and the monoclinic phase. Radha et al. [61] reported that for hydrated zirconia surfaces, the tetragonal phase is preferred at diameters smaller than $28 \pm 6 \mathrm{~nm}$, whereas the monoclinic phase is preferred for larger particles sizes. An estimate of particle size can be made from the BET surface area, and the size of the crystalline domains can be determined from X-ray diffractograms. A large discrepancy between the values suggests a significant solid-solid interfacial area; indeed Srinivasan et al. [62] observed small crystalline domains of 8-12 $\mathrm{nm}$ and a surface area of only $40 \pm 10 \mathrm{~m}^{2} \mathrm{~g}^{-1}$ for multiply twinned crystals of zirconia. Radha et al. [61] reported that the interfacial energy of zirconia amounts to only $20 \%$ of the surface energy. Hence, if there is a discrepancy, the BET surface area, which neglects the interfacial area and will overestimate the crystallite size, should reflect the size of the surface energy term better than the domain size, which accounts for the interfacial area and will underestimate the particle size. To derive the particle size from the BET surface area, the density of the monoclinic phase of $5.82 \mathrm{~g} \mathrm{~cm}^{-3}$ [63] was used, 
and particles of spherical shape und uniform size were assumed. The obtained diameter of $26 \mathrm{~nm}$ for pure zirconia is close to the stability crossover value; and, hence, the observation of a mixture seems to correspond to the thermodynamic situation.

The presence of sulfate results in a significantly higher surface area of zirconia, corresponding to an average particle diameter of about $15 \mathrm{~nm}$. Particles of this size should be tetragonal, and, indeed, these materials were phase pure within our detection limit. Surface sulfate species probably act as a barrier to crystal growth by preventing the olation and oxolation reactions by which small particles can connect during calcination of the hydrous precursor. Estimates of the area occupied by a sulfate group vary between $0.25 \mathrm{~nm}^{2}$ [64] and $0.5 \mathrm{~nm}^{2}$ [65]. Assuming each sulfate group requires an area of $0.5 \mathrm{~nm}^{2}$ [65], 5.7 $\mathrm{wt} \% \mathrm{SO}_{4}{ }^{2-}$ would be necessary to form a monolayer on a sample with a surface area of $135 \mathrm{~m}^{2} \mathrm{~g}^{-1}$. The sulfate content of sulfated zirconia was $4.2 \mathrm{wt} \%$ and thus coverage is only about $73 \%$. However, to prevent coalescence of two adjacent particles it may suffice if one surface is covered with sulfate. In addition, the temperature of $823 \mathrm{~K}$ may not have been high enough to instigate the phase transformation, and larger particles may exist although they are thermodynamically metastable. The adsorbed sulfate will also change the surface energies of the two phases, likely diminishing the difference, such that the stability crossover would already occur at a smaller particle size than for bare zirconia. The fact that the particles are tetragonal indicates that they are small enough to favor the tetragonal phase despite the diminished difference in surface energy.

The promoted samples, calcined at a temperature of $923 \mathrm{~K}$, exhibit surface areas of $105-115 \mathrm{~m}^{2} \mathrm{~g}^{-1}$, corresponding to particle sizes of $20-18 \mathrm{~nm}$. The sulfate coverage is within the accuracy of the estimate equal to that of sulfated zirconia. Traces of monoclinic zirconia at a promoter content of $0.5 \mathrm{wt} \%$ are explained by the somewhat larger particle size in comparison to sulfated zirconia and the higher temperature, which may provide enough activation energy for the transformation of kinetically stabilized tetragonal material. At a promoter content of $2.0 \mathrm{wt} \%$, the materials were purely tetragonal, consistent with the bulk stabilizing effect of lower valent cations.

\subsection{Thermal stability of surface species water and sulfate}

Thermal analysis has been performed on precursors $[31,66,67]$ or on calcined sulfated zirconia catalysts [6870]. The first two weight losses and the observation of first water and then $\mathrm{SO}_{2}$ and $\mathrm{O}_{2}$ in the effluent stream in the TGA-MS experiments on calcined samples are well documented in the literature [69]. Reported temperatures for water loss are around 373-383 K [69,71], consistent with our observation of $370 \mathrm{~K}$. Sulfate is reported to decompose between 873 and $1123 \mathrm{~K}$ [71], with the observed value of
$1080 \mathrm{~K}$ fitting well within this range. It has been proposed that $\mathrm{SO}_{2}$ and $\mathrm{O}_{2}$ are not directly released from the sample but form through decomposition of evolving $\mathrm{SO}_{3}$ [66]. The observed ratio between $\mathrm{SO}_{2}$ and $\mathrm{O}_{2}$ corresponds to a stoichiometry of 1:0.5, as expected for this decomposition. Thermodynamic equilibrium considerations indicate significant decomposition of $\mathrm{SO}_{3}$ into $\mathrm{SO}_{2}$ and $\mathrm{O}_{2}$ at $1080 \mathrm{~K}$, particularly at high dilution as in the inert gas stream during the TG-MS experiment. However, the maximum of $\mathrm{O}_{2}$ evolution is observed before the maximum of $\mathrm{SO}_{2}$ evolution, suggesting that decomposition takes place on the surface rather than being a secondary reaction in the gas phase. The ability of the sulfated zirconia to release $\mathrm{O}_{2}$, that is, to produce $\mathrm{O}_{2}$ in statu nascendi, is consistent with its observed oxidizing power $[35,67]$.

Little information is found in the literature on the third weight loss at temperatures of 1000-1350 K, which is characterized by the evolution of $\mathrm{SO}_{2}$ alone. Althues and Kaskel [71] reported that TG-MS data indicated the decomposition of bulk sulfate groups between 973 and 1273 $\mathrm{K}$; the gas phase products were not discussed in detail. Fărcaşiu et al. [72] proposed the presence of internal sulfate ions in the zirconia matrix on the basis of X-ray photoelectron spectra. $\mathrm{Li}$ and Gonzalez [69] observed m/e=64 $\left(\mathrm{SO}_{2}\right)$ at $1173 \mathrm{~K}$ during thermal analysis, and an additional signal at $\mathrm{m} / \mathrm{e}=65$ let them infer the formation of $\mathrm{HSO}_{2}$.

The evolution of $\mathrm{SO}_{2}$ during the third weight loss indicates a preceding or simultaneous redox reaction. $\mathrm{O}_{2}$ is not a product of this reaction. Oxygen vacancies $\mathrm{V}_{\mathrm{O}}{ }^{\circ}$, which are known to be present in tetragonal zirconia [27], require the presence of negative charges, that is, electrons, for charge balance somewhere in the crystal; these electrons can, for example, be located in the vacancy $\left(\mathrm{V}_{\mathrm{O}}{ }^{\circ}\right.$ or $\mathrm{V}_{\mathrm{O}}{ }^{\mathrm{x}}$ ) or on cations with a valence smaller than $+\mathrm{IV}$. Reduction of sulfur (+VI) by these electrons and filling of vacancies with $\mathrm{O}^{2-}\left(\mathrm{O}_{\mathrm{O}}{ }^{\mathrm{x}}\right)$ could explain the formation of $\mathrm{SO}_{2}$ without release of $\mathrm{O}_{2}$. This reaction seems to take place more easily in the presence of promoters, and a larger amount of $\mathrm{SO}_{2}$ is formed. Consistent with this data is the observation that promoters increase the number of surface $\mathrm{V}_{\mathrm{O}}^{+}$sites [Giliard et al. "unpublished results"]

The TG data indicate that sulfate is much more strongly bound than water - the products are volatile in both cases. At the end of the TG analysis, the samples were largely monoclinic. There are no heat signals indicating a phase transition without mass loss. The phase transformation must thus be associated with the loss of sulfate.

\subsection{Effect of adsorbed sulfate and other oxo- anion species on the thermal stability of support phase and implications for catalysis}

Sulfate, when added before calcination, prevents particle growth, as manifested by generally higher BET surface areas of sulfated in comparison to unsulfated zirconia materials $\left(138-147 \mathrm{~m}^{2} \mathrm{~g}^{-1}\right.$ vs. $\left.79-86 \mathrm{~m}^{2} \mathrm{~g}^{-1}\right)$. This phe- 
nomenon of higher support oxide surface area through addition of sulfate is generally observed, for example also for titania and tin (IV) oxide [72,73]. The stability towards sintering and phase transformation is maintained as long as the sulfate is attached to the surface. The sulfate on zirconia decomposes to volatile compounds at temperatures from 860 to $1230 \mathrm{~K}$. At these temperatures, particle growth can take place, and then the monoclinic phase becomes more stable.

Molybdate and tungstate are also known to stabilize the tetragonal phase, but cannot be easily volatilized and the tetragonal phase is maintained during calcination at temperatures as high as 1023-1073 K [74]. One can consider two scenarios, (i) during the thermal treatment the support crystals grow and no longer provide enough surface area to stabilize dispersed molybdate or tungstate, which will then form crystalline metal(VI)oxide, or (ii) the (poly)oxometallate is thermally destabilized and forms the oxide, thus allowing zirconia crystal growth and promoting the transition to the monoclinic phase. The melting points of $\mathrm{WO}_{3}$ and $\mathrm{MoO}_{3}$ are only $1746 \mathrm{~K}$ and $1068 \mathrm{~K}$ whereas that of $\mathrm{ZrO}_{2}$ is $2953 \mathrm{~K}$, which suggests according to Hüttig's considerations that the tungstate and molybdate species become mobile at much lower temperatures than zirconium oxide species. Thus, scenario (ii) is more likely; and sulfate, tungstate or molybdate function as separating agents.

Another oxide phase that is more thermally stable in the presence of sulfate is the anatase modification of titania. The situation is slightly different from that encountered with zirconia, because in the case of extended crystals, rutile is the stable phase at all temperatures and pressures [75], making the transformation into rutile allotropic. Like the tetragonal phase of zirconia, the brookite and anatase phases of titania become thermodynamically stable at small crystallite sizes, with anatase favored at the smallest crystallite sizes corresponding to surface areas larger than 45 $\mathrm{m}^{2} \mathrm{~g}^{-1}$ [45]. When sulfate is decomposed at temperature between $873-1073 \mathrm{~K}$, crystal growth and rutilization are observed [76]. These processes are believed to be accelerated by oxygen vacancies left behind after sulfate decomposition [76]

Phase instability of oxide catalysts can result in minor or severe transformations during operation. A mixed oxide phase may decompose altogether into individual oxides, for example, $\mathrm{MoO}_{3}$ is formed during use of heteropolyacids for the oxidation of methacrolein to methacrylic acid [77]. Such thermal decomposition of the active phase is of more concern during highly exothermic oxidation reactions with the possibility of hot spot formation. Titania is used at elevated temperatures of $623-773 \mathrm{~K}$ in the selective oxidation of o-xylene to phthalic anhydride oxidation and at $623-723 \mathrm{~K}$ to for selective catalytic reduction of $\mathrm{NO}_{\mathrm{x}}$ with ammonia [78]. Indeed, rutilization is reported as a problem in these processes [78 and references therein].

The phase stability of sulfated zirconia under isomerization conditions is of minor concern because of the moderate temperatures, which are typically in the range
298-523 K and thus well within the thermal stability of the sulfate.

\subsection{Effect of adsorbed water on the phase sta- bility of sulfated zirconia}

The presented data show that in water vaporsaturated atmosphere, the tetragonal phase in sulfated zirconia transforms into the monoclinic phase at temperatures only slightly above room temperature (Figure 5), whereas in manganese-promoted sulfated zirconia, such rapid transformation is not observed (Table 3). In the glovebox, in the absence of water, the phase composition of SZ was almost completely retained and that of $2.0 \mathrm{MnSZ}$ was stable.

Water vapor is known to accelerate the transformation of tetragonal to monoclinic zirconia [27 and references therein], and the degradation can be restricted through cation doping, for example with $\mathrm{Y}^{3+}$. Guo [27] attempted to mold the multiple mechanisms discussed and the available data into a consistent picture and proposed that first water adsorbs on the surface and $\mathrm{OH}^{-}$are formed, which then move along the grain boundaries and fill oxygen vacancies until the vacancy concentration is below that necessary for stabilization of the tetragonal phase. However, a phase transition could also be envisioned as a result of surface effects alone. Navrotsky [61] determined that the stability range for the tetragonal phase shrinks upon water adsorption. Crystallite sizes up to $34 \mathrm{~nm}$ are thermodynamically stable for a dehydrated material whereas a hydrated material will not be stable when the crystallite size exceeds 28 $\mathrm{nm}$. If this scenario is true, then only particles above a certain size should transform while smaller ones remain tetragonal, assuming that under the mild conditions applied here, particle growth is insignificant. The adsorption of water during storage under tropical conditions is evidenced by a higher water content of SZ relative to storage under ambient or dry conditions (Table 2).

Adsorption of water on manganese-promoted sulfated zirconia during storage under tropical conditions is evidenced by the higher weight loss during outgassing (Table 2 ) and the detection of molecularly adsorbed water by IR spectroscopy (Figure 4a). IR spectra also show the formation of additional $\mathrm{OH}$ groups (Figure $4 \mathrm{~b}$ ), consistent with the dissociation of water on the surface. Apparently, the presence of $2 \mathrm{wt} \%$ manganese, predominantly in the zirconia lattice, sufficiently stabilizes the tetragonal phase to prevent the partial monoclinization observed for sulfated zirconia.

\subsection{Catalytic performance after storage}

In general, the catalytic performance of the samples either remained unchanged or became worse during storage, indicating that the materials are transforming into a less active state. Assuming a thermodynamically more 
stable state is reached with age, this observation implies that a more stable material will be a less active catalyst. The degree of activity loss was determined by the storage atmosphere.

After 6 months, the maximum isomerization rate of SZ showed the following trend: glovebox> laboratory> tropical. The trend in the data in Figure 6 suggests that the steady state performance of SZ stored in the glovebox will eventually reach that of the fresh catalyst, indicating that changes inflicted during storage that affect the activity are reversed during activation and operation. Surface hydration and hydroxylation have been reported to be important for the catalytic performance of sulfated zirconia. SZ materials calcined in situ in a catalytic reactor and not exposed to ambient before the reaction were found to be not active, and had to be rehydrated [79]. Best performance was reported after addition of $75 \mu \mathrm{mol} \mathrm{g}^{-1} \mathrm{H}_{2} \mathrm{O}$ [80] or a $\mathrm{H}_{2} \mathrm{O}$ content of $200 \mu \mathrm{mol} \mathrm{g}^{-1}$ [79]. These values correspond to 0.14 and $0.36 \mathrm{wt} \% \mathrm{H}_{2} \mathrm{O}$. A ratio of Brønsted to Lewis acid sites of 2:1 was reported to yield highest activity [79], suggesting that in fact acidic $\mathrm{OH}$ groups are necessary, which may be formed after exposure to water.

The aged samples differ in the $\mathrm{H}_{2} \mathrm{O}$ content, as evidenced by weight loss during outgassing (Table 2). However, physisorbed water is completely removed after activation at $723 \mathrm{~K} \mathrm{[35];} \mathrm{hence} \mathrm{any} \mathrm{variations} \mathrm{in} \mathrm{activity}$ must result from variations in degree of hydroxylation. Dehydroxylation requires high temperatures; thus, most likely, the degree of hydroxylation of the SZ sample stored under ambient conditions increased whereas that of the sample in the glovebox remained constant. The increase in catalytic activity with time on stream of the gloveboxstored sample could be explained by hydroxylation through traces of water in the feed or through water that is formed as a side product of oxidative dehydrogenation of $n$-butane. The recovery may take many hours (Figure 6 ) because only few water molecules are available or the hydroxylation reaction, which requires dissociation of the adsorbed water, is slow.

The trends in the relative intensities of sulfate and $\mathrm{OH}$ stretching bands in the DRIFT spectra of $2.0 \mathrm{MnSZ}$ with aging in the glovebox, in the laboratory (not shown), and under tropical conditions demonstrate that the surface is further hydroxylated in the laboratory and under tropical conditions, providing indirect evidence also for what was presumed above to occur to SZ. Similar to SZ, hydroxylation could explain why the MnSZ catalyst that had been stored in the glovebox for six months started producing isobutane only after ca. $10 \mathrm{~h}$ on stream. In contrast to SZ, the maximum rate reached is only $1 / 10$ of that of the fresh sample, suggesting an additional effect on the activity. The sample is still completely tetragonal, and so phase change effects can be excluded. The observed variations in color from bluish to grayish indicate a change in the manganese valence, and shrinkage of the unit cell volume possibly indicates more oxygen vacancies. Manganese in these catalysts can be reduced during heating in inert gas $[42,81]$; it is thus conceivable that reduction takes place over months in the $\mathrm{O}_{2}$-depleted atmosphere of a glovebox. Activation was performed in inert gas so that a reduction would not be reversed. It was shown previously [42] that the maximum rate of isobutane formation increases with increasing average manganese valence after activation; this fact supports the hypothesis that manganese may have been reduced. Moreover, the maximum isomerization rate is in the order of magnitude of what would be expected for a nonpromoted sulfated zirconia, consistent with a largely disabled promoter.

The catalytic performance of SZ was significantly reduced after aging under tropical conditions (Figure 6), whereas that of $2.0 \mathrm{MnSZ}$ hardly changed (Figure 7a). The property of SZ that also changes significantly is the phase composition, with $10 \mathrm{wt} \%$ monoclinic phase after aging. It has been reported repeatedly that water vapor promotes monoclinization [27 and reference therein], and hence the phase change is ascribed to the effect of the water vapor. The activity is almost completely lost, and a correlation with the phase change would imply that the activity originated mainly from the fraction of material that transformed. The manganese promoter stabilizes the tetragonal phase against the transformation. The DRIFT spectra show extensive hydroxylation; specifically, the intensity of the $\mathrm{OH}$ groups absorbing at $3640 \mathrm{~cm}^{-1}$ increased, as seen in the spectra of the activated catalyst (Figure $4 b$ ). These $\mathrm{OH}$ groups are formed at the expense of strong Lewis acid sites capable of adsorbing $\mathrm{N}_{2}$ at room temperature (inset in Figure $4 \mathrm{~b}$ ). These modifications of the surface, which occur under tropical conditions, have apparently no consequences for the catalytic performance.

The loss of activity of SZ during storage in the laboratory is difficult to explain on the basis of the present data. The material retains the tetragonal phase, and the data obtained for $2.0 \mathrm{MnSZ}$ under tropical conditions indicate that even extensive hydroxylation does not affect the catalytic performance.

\subsection{Stability of phase and of sulfate during me- chanochemical treatments}

A tribochemical or mechanochemical treatment is usually applied to materials to increase the catalytic activity [82], for example by decreasing the particle size or introducing defects [83], or to achieve an intimate mixture between two phases, for example in a solvent-free preparation [84]. Frequently, phase transformations occur as a result of such treatments, and, in case of enantiotropes, a mechanochemical equilibrium may be approached [85].

Milling may lead to smaller particle size and, as a result, phases with the lower surface energies may become favored. Milling can also lead to fusion of particles to form larger ones; Criado et al. [86] observed such "coldwelding" during milling of an X-ray amorphous zirconia gel. Previous reports indicate tetragonal to monoclinic transformations of pure zirconia during pressing [87], grinding in a mortar [88], and ball milling [89]; the reverse transforma 


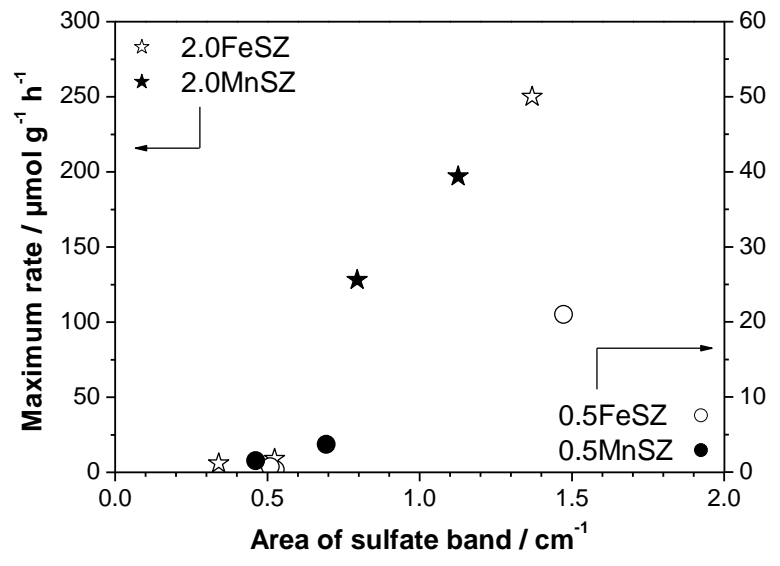

Fig. 10: Plot of maximum isomerization rate vs. area of sulfate band with maximum at $2755-2777 \mathrm{~cm}^{-1}$.

tion was also observed during ball milling [89]. Impurities may be introduced through the materials used to manufacture the milling assembly; for example, the complete transition of monoclinic to tetragonal zirconia was observed within $20 \mathrm{~h}$ when a planetary ball mill made of stainless steel was used [90].

The data in Table 4 demonstrate that partial monoclinization of promoted sulfated zirconia occurred during milling, consistent with previous results obtained with sulfated zirconia [28]. The tetragonal phase is more stable in the presence of promoters; with a higher amount of promoter leading to increased stability. This behavior can be explained with the formation of a solid solution and formation of oxygen vacancies as a consequence of a valence lower than $+\mathrm{IV}$ of the incorporated promoter cations. Manganese cations are more easily incorporated into the zirconia lattice than iron cations, and consequently iron is more likely to form a separate oxide phase with increasing content [47]. Hence, at $0.5 \mathrm{wt} \%$ content and most likely complete incorporation, iron and manganese are equally effective in the stabilization, whereas at $2.0 \mathrm{wt} \%$ content, manganese is more effective than iron (Table 4). The XAS data (Table 5) revealed no significant changes to the valence of manganese. The slight increase in BET surface area observed in two samples is in agreement with a slight decrease in the crystallite size observed for all the promoted samples. The crystals of the monoclinic phase were, if at all, smaller than those of the tetragonal phase, indicating that particle growth (through fusion) did not cause the transformation. Thus, there must have been metastable tetragonal crystals, and the milling provided the activation energy for the transformation, or the surface energy changed because milling affected the state of sulfate species, $\mathrm{OH}$ groups, or adsorbed water on the surface.

The nature of the sulfate species was investigated by IR spectroscopy, with focus on the species absorbing at 1385-1405 $\mathrm{cm}^{-1}$, which were assigned to adsorbed $\mathrm{SO}_{3}$ [29,91] or disulfate species [29], and were proposed to represent active species [57]. The overtone of this band, located at $2755-2770 \mathrm{~cm}^{-1}$ is more suitable for quantitative analysis than the fundamental; it is largely isolated from other bands and the reflectance is high $(\rho>0.7)$ so that it can be assumed that the Kubelka-Munk function should be proportional to the concentration of absorbing species. The absolute intensities of different DRIFT experiments may have to be compared with some caution; however, for all four samples the same trends were observed. The intensity of the vibrations at $2755-2770 \mathrm{~cm}^{-1}$ decreased significantly with increasing milling time, as illustrated in Figure 9 and summarized in Table 4. Concomitantly, the width of this band increased and the position shifted to lower wavenumbers. This particular sulfate species is altered as a result of the milling.

Earlier investigations found the sulfate content of sulfated zirconia to be reduced by about $10 \%$ after milling [28]. TG-MS data indicate that the sulfate content of the promoted samples decreased only marginally, hence transformation of the sulfate seems more likely than volatilization. The $\mathrm{SO}_{2}$ evolution from $0.5 \mathrm{FeSZ}$ during TG-MS shifted to slightly higher temperatures with increasing milling time (by 14 and by an additional $8 \mathrm{~K}$, respectively), whereas for $2.0 \mathrm{MnSZ}$ the onset remained unchanged. This small effect provides first evidence for the sulfate species being located on the transformed zirconia; the shift to higher temperature is consistent with the stronger interaction of $\mathrm{SO}_{3}$ with the monoclinic surface (vide supra).

The sulfate species are diminished more than the tetragonal content, providing additional evidence that these sulfate species are preferentially located on the crystallites that undergo a phase transformation. Indeed, it has been inferred previously that not all tetragonal material is catalytically active [55]. Whether the change of the sulfate bonding induces the phase transformation (which is known to start at the surface [27 and references therein]), or the transformation results in a variation of the sulfate structure, is not deducible from the data.

\subsection{Catalytic performance after milling}

All catalysts were less active after milling, indicating a loss of active sites. A linear correlation of rate with the tetragonal fraction was found for sulfated zirconia [54]; the corresponding plot obtained from the set of unmilled and milled promoted sulfated zirconia materials did not reveal such a correlation. A plot of the maximum rate vs. the area of the overtone band indicative of disulfate or $\mathrm{SO}_{3}$ species is shown in Figure 10. There exists a trend of increasing rate with increasing intensity of the band. Different slopes arise for various promoter contents and a linear regression does not pass through zero. These sulfate species are thus one of several essential ingredients to isomerization activity. Also, the maximum rate emphasizes only one aspect of the performance of a catalyst, and various sites have been made responsible for the activity at various times on stream [92]. 


\section{Conclusions}

The phase composition of small oxide particles is determined by the relative contributions of surface and bulk energies of the possible phases. The surface energy term may be altered through adsorbates whereas the bulk energy term can be altered through cation doping. These terms determine the stability range and the particle size (or surface area) at which a stability crossover will occur. Surface species such as oxoanions may act as separating agents during synthesis; they prevent particle growth. At small particle sizes, that is, high surface areas, the surface energy term becomes dominant and low surface energy phases may be favored.

Oxides with high reactivity such as sulfated zirconia appear to be on the verge of instability, and easily undergo phase transformation upon thermal or mechanical treatment or adsorption of water. The transformation proceeds unidirectional from the tetragonal to the monoclinic phase for sulfated zirconia. Except for some benefit through rehydroxylation immediately after calcination, a calcined catalyst only loses and never gains in performance through aging or milling, suggesting that achieving a thermodynamically more stable state implies a reduction in reactivity and thus catalytic activity. Since partial phase transformation goes along with major loss in activity, the least stable particles must bear the most active sites. Consistent with this hypothesis, the population of disulfate species, which are one essential ingredient of high activity, is overproportionally diminished along with partial monoclinization.

\section{References}

[1] Krylova AV, Ustimenko GA, Nefedova NV, Peev TM, Torocheshnikov NS (1986) Appl Catal 20:205

[2] Menon PG, Skaugset P (1994) Appl Catal A: General 115:295

[3] Menon PG (1994) Chem Rev 94:1021

[4] Ruckenstein E in Catalyst Deactivation, Delmon B, Froment GF (Eds.) (1994) Stud Surf Sci Catal 88:33

[5] Moulijn JA, van Diepen AE, Kapteijn F (2001) Appl Catal A: General 212:3

[6] Bartholomew CH (2001) Appl Catal A: General 212:17

[7] Spencer MS, Twigg MV (2005) Ann Rev Mater Res $35: 427$

[8] Garvie RC (1965) J Phys Chem 69:1238

[9] Holmes HF, Fuller EL, Gammage RB (1972) J Phys Chem 76:1497

[10] McHale JM, Auroux A, Perrotta AJ, Navrotsky A (1997) Science 277:788

[11] Hüttig GF in Handbuch der Katalyse, Vol. 6, Heterogene Katalyse III, (Ed. Schwab GM), Springer, Wien, 1943, p. 378, 388

[12] Tammann G, "Lehrbuch der Metallkunde", $4^{\text {th }}$ ed., Verlag Voss, Berlin 1929

[13] Merkle R, Maier J (2005) Z Anorg Allg Chem 631:1163

[14] Buffat Ph, Borel JP (1975) Phys Rev A 13:2287

[15] Wang X, Coleman J, Jia X, White JL (2002) J Phys Chem B 106:4941
Although the action of the promoters is complex, one emerging function of promoters such as iron or manganese is the stabilization of the tetragonal phase, making promoted catalysts much more stable during storage or treatment.

Catalytic activity has often been associated with metastability of materials, and the data presented here support that association. Transformations during storage may affect the initial but also the steady-state activity of catalyst materials. Catalyst stability has important ramifications for the transport and storage of catalysts, and for the correlation of data that are generated using various methods of specimen preparation or are collected at varying sample age.

\section{Acknowledgements}

The authors thank Gisela Lorenz for BET measurements and assistance with sample preparation, Edith Kitzelmann for XRD measurements, Frank Girgsdies for assistance with XRD analysis, Thorsten Ressler and the staff at Hasylab Beamline E4 for XAS measurements; Anja Hoffmann for BET measurements, MEL Chemicals for the zirconia precursors, and Robert Schlögl for his continuous support of this project. Funding by DFG (JE 267/2-1) is gratefully acknowledged.
[16] Madon RJ, Liu X, Sanchez-Castillo M, Dumesic JA (2003) Proceedings of the $18^{\text {th }}$ North American Catalysis Society Meeting, Cancun/Mexico, p. 17

[17] Bron M, Teschner D, Wild U, Steinhauer B, Knop-Gericke A, Volckmar C, Wootsch A, Schlögl R, Claus P (2008) Appl Catal A: General 341:127

[18] Hino M, Kobayashi S, Arata K (1979) J Am Chem Soc 101:6439

[19] Hino M, Arata K (1980) J Chem Soc Chem Commun :851

[20] Song X, Sayari Y (1996) Catal Rev Sci Eng 38:329

[21] Holm VCF, Bailey GC (1962) US Patent 3032 599, assigned to Philips Petroleum Co

[22] Hollstein EJ, Wie JT, Hsu CY (1990) US Patent 4918041 , assigned to Sun Refining and Marketing Co

[23] Hsu C-Y, Heimbuch CR, Armes CT, Gates BC (1992) J Chem Soc Chem Commun :1645

[24] Lange FC, Cheung T-K, Gates BC (1996) Catal Lett 41:95

[25] Morterra C, Cerrato G, Pinna F, Signoretto M (1995) J Catal 157:109

[26] Stichert W, Schüth F, Kuba S, Knözinger H (2001) J Catal 198:277

[27] Guo X (2004) Chem Mater 16:3988

[28] Klose BS, Jentoft RE, Hahn A, Ressler A, Kröhnert J, Wrabetz S, Yang X, Jentoft FC (2003) J Catal 217:487

[29] Hofmann A, Sauer J (2004) J Phys Chem B 108:14652

[30] Li X, Nagaoka K, Lercher JA (2004) J Catal 227:130 
[31] Srinivasan R, Keogh RA, Milburn DR, Davis BH (1995) J Catal 153:123

[32] Sikabwe EC, Coelho MA, Resasco DE, White RL (1995) Catal Lett 34:23

[33] Srinivasan R, Keogh RA, Ghenciu A, Fărcaşiu D, Davis BH (1996) J Catal 158:502

[34] Ng FTT, Horvát N (1995) Appl Catal A: General 123:L197

[35] Klose BS, Jentoft FC, Schlögl R, Subbotina IR, Kazansky VB (2005) Langmuir 21:10564

[36] Keogh RA, Srinivasan R, Davis BH (1995) J Catal 151:292

[37] Hahn A, Ressler T, Jentoft RE, Jentoft FC (2001) Chem Commun :537

[38] Hahn AHP, Jentoft RE, Ressler T, Weinberg G, Schlögl R, Jentoft FC (2005) J Catal 236:324

[39] Kraus W, Nolze G, Federal Institute for Materials Research and Testing, Rudower Chaussee 5, 12489 Berlin, Germany (http://users.omskreg.ru/ kolosov/bam/a_v/v_1/powder/e_cell.htm; accessed July 6, 2005)

[40] Inorganic Crystal Structure Database (ICSD), maintained by the Fachinformationszentrum (FIZ) Karlsruhe (http://icsd.fkf.mpg.de; accessed July 6, 2005).

[41] Klose BS, Jentoft FC, Schlögl R (2005) J Catal 233:68

[42] Jentoft RE, Hahn AHP, Jentoft FC, Ressler T (2005) Phys Chem Chem Phys 7:2830

[43] Ressler T, Brock SL, Wong J, Suib SL (1999) J Phys Chem B 103:6407

[44] Luo J, Stevens R (1999) J Am Ceram Soc 82:1922

[45] Navrotsky A (2009) Int J Quantum Chem 109:2647

[46] Basu B (2005) Int Mater Rev 50:245

[47] Jentoft FC, Hahn A, Kröhnert J, Lorenz G, Jentoft RE, Ressler T, Wild U, Schlögl R, Häßner C, Köhler K (2004) J Catal 224:124

[48] Stöcker J, Collongues R (1957) Compt Rend 245:695

[49] Fernández López E, Sánchez Escribano V, Resino C, Gallardo-Amores JM, Busca G (2001) Appl Catal B: Environmental 29:251

[50] Stöcker J (1960) Ann Chim 5:1459

[51] Keshavaraja A, Ramaswamy AV (1996) Appl Catal B: Environmental 8:L1

[52] Fărcaşiu D, Li JQ, Cameron S (1997) Appl Catal A: General 154:173

[53] Vera CR, Yori JC, Pieck CL, Irusta S, Parera JM (2003) Appl Catal A: General 240:161

[54] Li X, Nagaoka K, Olindo R, Lercher JA (2006) J Catal 238:39

[55] Li X, Nagaoka K, Simon LJ, Lercher JA, Wrabetz S, Jentoft FC, Breitkopf C, Matysik S, Papp H (2005) J Catal 230:214

[56] Bensitel M, Saur O, Lavalley JC, Mabilon G (1987) Mater Chem Phys 17:249

[57] Li X, Nagaoka K, Simon LJ, Olindo R, Lercher JA, Hofmann A, Sauer J (2005) J Am Chem Soc 127:16159

[58] Cerofolini GF (1975) Surf Sci 51:333

[59] Ushakov SV, Navrotsky A (2005) Appl Phys Lett 87:164103

[60] Pokrovski K, Jung KT, Bell AT (2001) Langmuir 17:4297

[61] Radha AV, Bomati-Miguel O, Ushakov SV, Navrotsky A, Tartaj P (2009) J Am Ceram Soc 92:133
[62] Srinivasan R, Davis BH, Cabin OB, Hubbard CR (1992) J Am Ceram Soc 75:1217

[63] D'Ans Lax, Taschenbuch für Chemiker und Physiker, Band III Elemente, anorganische Verbindungen und Materialien, Ed. R. Blachnik, $4^{\text {th }}$ edition, Springer-Verlag, Berlin 1998

[64] Katada N, Endo J-i, Notsu K-i, Yasunobu N, Naito N, Niwa M (2000) J Phys Chem B 104:10321

[65] Fraenkel D (1997) Ind Eng Chem Res 36:52

[66] Chokkaram S, Srinivasan R, Milburn DR, Davis BH (1994) J Coll Interf Sci 165:160

[67] Srinivasan R, Keogh RA, Milburn DR, Davis BH (1995) J Catal 153:123

[68] Li B, Gonzalez RD (1996) Ind Eng Chem Res 35:3141

[69] Coelho MA, Alvarez WE, Sikabwe EC, White RL, Resasco DE (1996) Catal Today 28:415

[70] Chen S-Y, Jang L-Y, Cheng S (2006) J Phys Chem B 110:11761

[71] Althues H, Kaskel S (2002) Langmuir 18:7428

[72] Corma A, Martínez A, Martínez C (1996) Appl Catal A: General 144:249

[73] Jentoft FC in Handbook of Hetereogeneous Catalysis, Vol. 1 (Eds. Ertl G, Knözinger H, Schüth F, Weitkamp J), WILEY-VCH, Weinheim, $2^{\text {nd }}$ Ed., 2008

[74] Zhao B-Y, Xu X-P, Ma H-R, Sun D-H, Gao J-M (1997) Catal Lett 45:237

[75] Navrotsky A, Kleppa OJ (1967) J Am Ceram Soc 50:626

[76] Bokhimi X, Morales A, Ortíz E, López T, Gómez R, Navarrete J (2004) J Sol-Gel Sci Technol 29:31

[77] Marosi L, Cox G, Tenten A, Hibst H (2000) J Catal 194:140

[78] Oliveri G, Ramis G, Busca G, Sanchez Escribano V (1993) J Mater Chem 3:1239

[79] Song SX, Kydd RA (1998) J Chem Soc Faraday Trans 94:1333

[80] González MR, Kobe JM, Fogash KB, Dumesic JA (1996) J Catal 160:290

[81] Klose BS, Jentoft FC, Joshi P, Trunschke A, Schlögl R, Subbotina IR, Kazansky VB (2006) Catal Today 116:121

[82] Buyanov RA, Molchanov VV, Boldyrev VV (2009) Catal Today 144:212

[83] Rühle T, Timpe O, Pfänder N, Schlögl R (2000) Angew Chem Int Ed 39:4379

[84] Jentoft FC, Schmelz H, Knözinger H (1997) Appl Catal A: General 161:167

[85] Schrader R, Weigelt D (1970) Z anorg allg Chem 372: 228

[86] Criado JM, González M, Diánez MJ, Pérez-Maqueda LA, Málek J (2007) J Phys Chem Solids 68:824

[87] Agron PA, Fuller EL Jr, Holmes HF (1975) J Colloid Interf Sci 52:553

[88] Whitney ED (1965) Trans Faraday Soc 61:1991

[89] Bailey JE, Lewis D, Librant ZM, Porter LJ (1972) Trans J Brit Ceram Soc 71:25

[90] Štefanić G, Musić S, Gajović A (2006) Mater Res Bull 41:764

[91] Babou F, Coudurier G, Védrine JC (1995) J Catal 152:341

[92] Kim SY, Goodwin JG Jr, Galloway D (2000) Catal Today $63: 21$ 